\title{
Partitioning of hydrogen peroxide in gas-liquid and gas-aerosol phases
}

\author{
Xiaoning Xuan, Zhongming Chen, Yiwei Gong, Hengqing Shen, and Shiyi Chen \\ State Key Laboratory of Environmental Simulation and Pollution Control, College of Environmental Sciences and \\ Engineering, Peking University, Beijing, 100871, China
}

Correspondence: Zhongming Chen (zmchen@pku.edu.cn)

Received: 14 January 2020 - Discussion started: 20 January 2020

Revised: 20 March 2020 - Accepted: 16 April 2020 - Published: 12 May 2020

\begin{abstract}
Hydrogen peroxide $\left(\mathrm{H}_{2} \mathrm{O}_{2}\right)$ is a vital oxidant in the atmosphere and plays critical roles in the oxidation chemistry of both liquid and aerosol phases. The partitioning of $\mathrm{H}_{2} \mathrm{O}_{2}$ between the gas and liquid phases, or the aerosol phase, could affect its abundance in these condensed phases and eventually the formation of secondary components. However, the partitioning processes of $\mathrm{H}_{2} \mathrm{O}_{2}$ in gas-liquid and gas-aerosol phases are still unclear, especially in the ambient atmosphere. In this study, field observations of gas-, liquid-, and aerosolphase $\mathrm{H}_{2} \mathrm{O}_{2}$ were carried out in the urban atmosphere of Beijing during the summer and winter of 2018. The effective field-derived mean value of Henry's law constant $\left(H_{\mathrm{A}}^{\mathrm{m}}\right.$, $2.1 \times 10^{5} \mathrm{M} \mathrm{atm}^{-1}$ ) was 2.5 times of the theoretical value in pure water $\left(H_{\mathrm{A}}^{\mathrm{t}}, 8.4 \times 10^{4} \mathrm{M} \mathrm{atm}^{-1}\right)$ at $298 \pm 2 \mathrm{~K}$. The effective derived gas-aerosol partitioning coefficient $\left(K_{\mathrm{P}}^{\mathrm{m}}\right.$, $\left.3.8 \times 10^{-3} \mathrm{~m}^{3} \mu \mathrm{g}^{-1}\right)$ was 4 orders of magnitude higher on average than the theoretical value $\left(K_{\mathrm{P}}^{\mathrm{t}}, 2.8 \times 10^{-7} \mathrm{~m}^{3} \mu \mathrm{g}^{-1}\right)$ at $270 \pm 4 \mathrm{~K}$. Beyond following Henry's law or Pankow's absorptive partitioning theory, the partitioning of $\mathrm{H}_{2} \mathrm{O}_{2}$ in the gas-liquid and gas-aerosol phases in the ambient atmosphere was also influenced by certain physical and chemical reactions. The average concentration of liquid-phase $\mathrm{H}_{2} \mathrm{O}_{2}$ in rainwater during summer was $44.12 \pm 26.49 \mu \mathrm{M}$. In $69 \%$ of the collected rain samples, the measured level of $\mathrm{H}_{2} \mathrm{O}_{2}$ was greater than the predicted value in pure water calculated by Henry's law. In these samples, $41 \%$ of the measured $\mathrm{H}_{2} \mathrm{O}_{2}$ was from gas-phase partitioning, while most of the rest may be from residual $\mathrm{H}_{2} \mathrm{O}_{2}$ in raindrops. In winter, the level of aerosol-phase $\mathrm{H}_{2} \mathrm{O}_{2}$ was $0.093 \pm 0.085 \mathrm{ng} \mathrm{\mu g}^{-1}$, which was much higher than the predicted value based on Pankow's absorptive partitioning theory. The contribution of partitioning of the gas-phase $\mathrm{H}_{2} \mathrm{O}_{2}$ to the aerosol-phase $\mathrm{H}_{2} \mathrm{O}_{2}$ for-
\end{abstract}

mation was negligible. The decomposition/hydrolysis rate of aerosol-phase organic peroxides could account for $11 \%$ $74 \%$ of the consumption rate of aerosol-phase $\mathrm{H}_{2} \mathrm{O}_{2}$, and the value depended on the composition of organic peroxides in the aerosol particles. Furthermore, the heterogeneous uptake of $\mathrm{HO}_{2}$ and $\mathrm{H}_{2} \mathrm{O}_{2}$ on aerosols contributed to $22 \%$ and $2 \%$ of the aerosol-phase $\mathrm{H}_{2} \mathrm{O}_{2}$ consumption, respectively.

\section{Introduction}

Hydrogen peroxide $\left(\mathrm{H}_{2} \mathrm{O}_{2}\right)$ is a crucial oxidant in liquid- and aerosol-phase chemistry (Reeves and Penkett, 2003). Additionally, it serves as a temporary reservoir species that cycles and redistributes the $\mathrm{HO}_{x}$ radicals (Lee et al., 2000; Tong et al., 2016; Crowley et al., 2018). Owing to high solubility in water (O'Sullivan et al., 1996) and high reaction rate with reducing substances (Seinfeld and Pandis, 2006), $\mathrm{H}_{2} \mathrm{O}_{2}$ plays a vital part in the fast formation of sulfate $\left(\mathrm{SO}_{4}^{2-}\right)$ and fine particles $\left(\mathrm{PM}_{2.5}\right)$ during heavy haze episodes (Stein and Saylor, 2012; Qin et al., 2018; Ye et al., 2018; Liu et al., 2020). Moreover, $\mathrm{H}_{2} \mathrm{O}_{2}$, as a typical reactive oxygen species (ROS), has adverse health effects and contributes to incidences of lung cancer, asthma, and cardiopulmonary disease (Gurgueira et al., 2002; Zhao et al., 2011; Campbell et al., 2019).

$\mathrm{H}_{2} \mathrm{O}_{2}$ in the liquid and aerosol phases is generally assumed to originate from the partitioning of gas-phase $\mathrm{H}_{2} \mathrm{O}_{2}$, and the partitioning of $\mathrm{H}_{2} \mathrm{O}_{2}$ between the gas-liquid and gasaerosol phases is expected to obey Henry's law and Pankow's absorptive partitioning theory, respectively. Research on the partitioning process of $\mathrm{H}_{2} \mathrm{O}_{2}$ may contribute to a clearer understanding of the sources of limiting oxidants, as well as 
the contribution of $\mathrm{H}_{2} \mathrm{O}_{2}$ to sulfate formation in the liquid and aerosol phases. In this study, we define the field-derived ratios of the measured levels of gas-to-liquid and gas-toaerosol phases as the effective Henry's law constant and the effective gas-aerosol partitioning coefficient, respectively.

However, it is noteworthy that the predicted liquid-phase concentration of $\mathrm{H}_{2} \mathrm{O}_{2}$ in rainwater using Henry's law was not enough to account for the measured level, and a large amount of liquid-phase $\mathrm{H}_{2} \mathrm{O}_{2}$ was produced from other reactions (Liang et al., 2013). Chung et al. (2005) demonstrated that the salting-in effect could double the solubility of $\mathrm{H}_{2} \mathrm{O}_{2}$ in salt solutions with concentrations up to $10 \mathrm{M}$, but the ionic strength in rainwater was too low to impose the salting-in effect ( $\mathrm{Li}$ et al., 2020). Therefore, we need to seek other possible explanations. In addition, the level of gas-phase $\mathrm{H}_{2} \mathrm{O}_{2}$ at the ground after a shower was higher than before, suggesting that raindrops could release $\mathrm{H}_{2} \mathrm{O}_{2}$ into the gas phase at the ground (Hua et al., 2008). This provided new possibilities for explaining the high level of $\mathrm{H}_{2} \mathrm{O}_{2}$ in rainwater. However, the falling of raindrops is a complex process that involves several uncertainties, so observational studies are needed to quantitatively explain the high concentration of $\mathrm{H}_{2} \mathrm{O}_{2}$ in rainwater.

The measured level of $\mathrm{H}_{2} \mathrm{O}_{2}$ in aerosol particles could be 2 orders of magnitude higher than the theoretical value from gas-aerosol partitioning (Hasson and Paulson, 2003; Arellanes et al., 2006), and it was confirmed that considerable $\mathrm{H}_{2} \mathrm{O}_{2}$ could be produced from redox reactions in aerosols (e.g. transition metals involved) (Charrier et al., 2014). However, it is noticeable that continuous redox reactions are assisted by available reductants, so it is impossible for ambient aerosols to generate $\mathrm{H}_{2} \mathrm{O}_{2}$ from reactions involving transition metals without an additional reducing agent (Shen et al., 2011). Recently, numerous studies have reported the decomposition of organic peroxides in the aerosol phase (Krapf et al., 2016; Riva et al., 2017). Li et al. (2016) suggested that the decomposition/hydrolysis of organic peroxides on secondary organic aerosol particles could substantially raise the level of $\mathrm{H}_{2} \mathrm{O}_{2}$. Qiu et al. (2019) proposed that $\alpha$-hydroxyalkyl-hydroperoxides could be easily decomposed into $\mathrm{H}_{2} \mathrm{O}_{2}$ within $2 \mathrm{~h}$ in $\geq 10 \%$ water mixtures. However, the quantification of organic peroxides is difficult because of their instability (Zhao et al., 2018). The decomposition of labile organic peroxides should be studied in fine particles in heavily polluted areas. In addition, as $\mathrm{H}_{2} \mathrm{O}_{2}$ is easily adsorbed and absorbed onto aerosol particles (Zhao et al., 2011; Wu et al., 2015), its heterogeneous uptake should also be considered. Hence, field measurements are needed for a quantitative evaluation of the sources of aerosol-phase $\mathrm{H}_{2} \mathrm{O}_{2}$ other than gas-phase partitioning.

Compared to gas-phase $\mathrm{H}_{2} \mathrm{O}_{2}$, it is challenging to quantitatively understand the chemistry of $\mathrm{H}_{2} \mathrm{O}_{2}$ in the liquid and aerosol phases. To the best of our knowledge, this is the first study to measure $\mathrm{H}_{2} \mathrm{O}_{2}$ in gas-liquid or gas-aerosol phases simultaneously in a heavily polluted area, i.e. Beijing, which provides a good opportunity to better understand the parti- tioning of $\mathrm{H}_{2} \mathrm{O}_{2}$ in different phases. The objectives of this study are to explore the partitioning of $\mathrm{H}_{2} \mathrm{O}_{2}$ in the gasliquid and gas-aerosol phases in the ambient atmosphere, and to seek possible sources in addition to gas-phase partitioning that could increase $\mathrm{H}_{2} \mathrm{O}_{2}$ concentration in the liquid and aerosol phases.

\section{Experimental}

\subsection{Measurement site}

The online gas-phase measurement of peroxides was performed at the Peking University (PKU) site $\left(39.99^{\circ} \mathrm{N}\right.$, $116.30^{\circ} \mathrm{E}$ ), situated in the northwest of urban Beijing. The PKU site is a typical city site in a heavily polluted area in Beijing, with two main trunk roads of traffic to the east and south. The relative apparatus was placed on the roof of a building that was $\sim 26 \mathrm{~m}$ above ground level. In this study, we used two measurement periods at the PKU site: 23 July10 August 2018 and 25 August-11 September 2018 (BJ2018Summer hereafter) and 21 December 2018-5 January 2019 (BJ-2018Winter hereafter).

\subsection{Measurement methods}

\subsubsection{Gas-phase peroxides}

The concentrations of gas-phase peroxides were measured in both BJ-2018Summer and BJ-2018Winter using highperformance liquid chromatography (HPLC, Agilent 1200, USA) with a time resolution of $21 \mathrm{~min}$. The HPLC coupled with the post-column enzyme derivatization method could distinguish $\mathrm{H}_{2} \mathrm{O}_{2}$ from organic peroxides. This method is well established (Hua et al., 2008; He et al., 2010; Wang et al., 2016) and is only briefly described here. Ambient air was drawn into a glassy scrubbing coil at a flow rate of $2.7 \mathrm{slpm}$ (standard litre per minute). $\mathrm{H}_{3} \mathrm{PO}_{4}$ solution $\left(5 \times 10^{-3} \mathrm{M}\right)$ was added to the scrubbing coil at $0.2 \mathrm{~mL} \mathrm{~min}^{-1}$ to dissolve $\mathrm{H}_{2} \mathrm{O}_{2}$ from ambient air. The collection efficiency of $\mathrm{H}_{2} \mathrm{O}_{2}$ was validated to be close to $100 \%$. Then, the mixture was injected into the HPLC instrument with the mobile phase $\left(\mathrm{H}_{3} \mathrm{PO}_{4}, 5 \times 10^{-3} \mathrm{M}\right)$. Peroxides separated by the column reacted stoichiometrically with para-hydroxyphenylacetic acid (PHPAA) under the haemin catalyst, generating stable PHPAA dimers that were measured by a fluorescence detector. The peroxides were identified and quantified using standard samples, and the detection limit (DL) of the gas-phase $\mathrm{H}_{2} \mathrm{O}_{2}$ was about 10 parts per trillion by volume (pptv). The values below DL were replaced by DL divided by the square root of two (the same hereafter). The gas-phase samples during BJ2018Summer were used for the partitioning analysis in the gas-liquid phase, while the data of BJ-2018Winter were used to study the partitioning in the gas-aerosol phase. 


\subsubsection{Liquid-phase peroxides}

Rain samples were collected by a custom-built glass funnel and were used for the analysis of liquid-phase peroxides in BJ-2018Summer. During the observation period, the collection of rain samples was well organized depending on the intensity, amount, and duration of the rain. Because the peroxides were easy to break down, the collected rain samples were preserved in brown vials at $277 \mathrm{~K}$ until being analysed with HPLC within $6 \mathrm{~h}$. The subsequent detection method for the liquid-phase peroxides was the same as for the gas-phase peroxides. In all, we collected 60 rain samples during seven rain episodes, and the DL of the liquid-phase $\mathrm{H}_{2} \mathrm{O}_{2}$ was about $8 \mathrm{nM}$. The specific dates of the rain events in chronological order were 24 July, 25 July, 5 August, 6 August, 8 August, 30 August, and 2 September.

\subsubsection{Aerosol-phase peroxides}

Aerosol-phase samples were gathered on Teflon filters (Whatman $^{\mathrm{TM}}, 47 \mathrm{~mm}$ diameter and $2 \mu \mathrm{m}$ pore size) using a four-channel filter sampler (Wuhan Tianhong TH-16A, China) at $16.7 \mathrm{slpm}$ during BJ-2018Winter. Teflon filters were supported by stainless-steel filter holders during a $11.5 \mathrm{~h}$ sampling interval. We immediately disposed of two Teflon filters for the analysis of peroxides and total peroxides (TPOs), and the remaining filters were kept under refrigeration at $255 \mathrm{~K}$ for subsequent component analysis. For analysing the aerosol-phase peroxides, the Teflon filters were immediately extracted with $10 \mathrm{~mL} \mathrm{H}_{3} \mathrm{PO}_{4}$ in conical flasks and placed on a shaker to be blended thoroughly at $277 \mathrm{~K}$ and $180 \mathrm{rpm}$ for $15 \mathrm{~min}$. Then, the extracted solution was measured with HPLC within $40 \mathrm{~min}$. The remained extracted solution was stored at $255 \mathrm{~K}$ away from light for subsequent measurement of $\mathrm{H}_{2} \mathrm{O}_{2}$ concentration variation with time, and details of the experimental conditions of the extracted solution are shown in the Supplement. Photochemical reactions of aerosols may produce aerosol-phase $\mathrm{H}_{2} \mathrm{O}_{2}$ (Zhou et al., 2008), and the effect of the photochemical reactions on the level of $\mathrm{H}_{2} \mathrm{O}_{2}$ in the extracted solution is discussed in the Supplement. Furthermore, the extracted solution was also used for the measurement of TPOs using the iodometric spectrophotometric method, which could measure $\mathrm{H}_{2} \mathrm{O}_{2}$ as well as organic peroxides (Nozaki, 1946; Banerjee and Budke, 1964). The extraction efficiency has been discussed in our previous work (Li et al., 2016), and we did not correct the total peroxides level. After the oxygen in the extracted solution was blown off by bubbling with nitrogen for $5 \mathrm{~min}$, $250 \mu \mathrm{L}$ of potassium iodide solution (KI, $0.75 \mathrm{M}$ ) was added to the solution to react with TPOs in the dark for $12-24 \mathrm{~h}$ (Reactions $\mathrm{R} 1$ and $\mathrm{R} 2$ ). The reaction product $\mathrm{I}_{3}^{-}$ion could be detected using UV-Vis spectrophotometry (Beijing PERSEE TU-1810, China) at the wavelength of $420 \mathrm{~nm}$. A total of 31 aerosol-phase samples were analysed, and the DL of aerosolphase $\mathrm{H}_{2} \mathrm{O}_{2}$ was close to $0.24 \mathrm{ng} \mathrm{m}^{-3}\left(0.006 \mathrm{ng} \mathrm{\mu g}^{-1}\right)$.
To avoid the matrix influence on samples (i.e. Teflon filters and the $\mathrm{H}_{3} \mathrm{PO}_{4}$ solution), we measured the concentration of blank samples in every extraction. The level of $\mathrm{H}_{2} \mathrm{O}_{2}$ in three-quarters of the blank samples was equal to $0 \mu \mathrm{M}$, and the concentration of $\mathrm{H}_{2} \mathrm{O}_{2}$ in the remaining blank samples was below $10 \%$ of that in the ambient aerosol samples. To prevent the matrix influence, we deducted the background values of the samples. In addition, to ensure that the measured $\mathrm{H}_{2} \mathrm{O}_{2}$ was attributed to aerosols collected on Teflon filters, we performed experiments to demonstrate that the physical adsorption on clean Teflon filters without aerosols was responsible for $15 \%$ of the measured $\mathrm{H}_{2} \mathrm{O}_{2}$ in aerosol samples. The details are available in Fig. S1 in the Supplement. In this study, we did not correct for the effect of the physical adsorption on the aerosol-phase $\mathrm{H}_{2} \mathrm{O}_{2}$.

$$
\begin{aligned}
& 3 \mathrm{I}^{-}+\mathrm{H}_{2} \mathrm{O}_{2}+2 \mathrm{H}^{+} \rightarrow \mathrm{I}_{3}^{-}+2 \mathrm{H}_{2} \mathrm{O} \\
& \mathrm{R}_{1} \mathrm{OOR}_{2}+3 \mathrm{I}^{-}+2 \mathrm{H}^{+} \rightarrow \mathrm{I}_{3}^{-}+\mathrm{R}_{1} \mathrm{OH}+\mathrm{R}_{2} \mathrm{OH}
\end{aligned}
$$

\subsubsection{Other components and meteorological parameters}

Water-soluble cations $\left(\mathrm{Na}^{+}, \mathrm{NH}_{4}^{+}, \mathrm{K}^{+}, \mathrm{Mg}^{2+}\right.$, and $\left.\mathrm{Ca}^{2+}\right)$ as well as anions $\left(\mathrm{Cl}^{-}, \mathrm{NO}_{3}^{-}\right.$, and $\left.\mathrm{SO}_{4}^{2-}\right)$ were measured with ion chromatography (IC, Dionex ICS2000 and ICS2500, USA). Transition metal elements deposited on Teflon filters were measured with inductively coupled plasma mass spectrometry (ICP-MS, Bruker aurora M90, Germany). The mass concentration of $\mathrm{PM}_{2.5}$ was measured with a TEOM 1400a analyser. Meteorological parameters (ambient temperature, relative humidity, and wind speed) and major trace gases $\left(\mathrm{O}_{3}\right.$, $\mathrm{SO}_{2}, \mathrm{NO}, \mathrm{NO}_{2}, \mathrm{NO}_{x}$, and $\mathrm{CO}$ ) were monitored simultaneously using a series of commercial instruments (Met One Instruments Inc., Thermo 49i, 43i, 42i, and 48i).

\subsection{Estimation of effective partitioning coefficients}

To estimate the effective partitioning coefficients, we could use the field-derived Henry's law constant for the gas-liquid phase and the gas-aerosol partitioning coefficient for the gasaerosol phase (Pankow, 1994), which are estimated according to Eqs. (1) to (4):

$$
\begin{aligned}
H_{\mathrm{A}}^{\mathrm{t}} & =8.4 \times 10^{4} \mathrm{Matm}^{-1}, \\
H_{\mathrm{A}}^{\mathrm{m}} & =\frac{C_{\mathrm{aq}}^{\mathrm{m}}}{C_{\mathrm{g}}^{\mathrm{m}}}, \\
K_{\mathrm{P}}^{\mathrm{t}} & =\frac{R T_{\mathrm{W}} f_{\mathrm{om}}}{10^{6} \mathrm{MW}_{\mathrm{OM}} \zeta p_{\mathrm{L}}^{0}}, \\
K_{\mathrm{P}}^{\mathrm{m}} & =\frac{C_{\mathrm{p}}^{\mathrm{m}}}{C_{\mathrm{g}}^{\mathrm{m}} \mathrm{TSP}}, \\
H_{\mathrm{P}}^{\mathrm{m}} & =\frac{C_{\mathrm{p}}^{\mathrm{m}}}{C_{\mathrm{g}}^{\mathrm{m}}},
\end{aligned}
$$

In Eqs. (1) and (2), $C_{\mathrm{aq}}^{\mathrm{m}}$ is the liquid-phase level of $\mathrm{H}_{2} \mathrm{O}_{2}$ (M); $C_{\mathrm{g}}^{\mathrm{m}}$ is the partial pressure of the gas-phase $\mathrm{H}_{2} \mathrm{O}_{2}$ (atm); 
and $H_{\mathrm{A}}^{\mathrm{t}}$ and $H_{\mathrm{A}}^{\mathrm{m}}$ are the theoretical value in pure water and the effective field-derived Henry's law constant, respectively $\left(\mathrm{M} \mathrm{atm}^{-1}\right)$ (Sander et al., 2011). The average temperature during rainfall in summer $\left(T_{\mathrm{S}}\right)$ is $298 \pm 2 \mathrm{~K}$ (mean \pm standard deviation, the same hereafter). In Eq. (3), $K_{\mathrm{P}}^{\mathrm{t}}$ is the theoretical value of the gas-aerosol partitioning coefficient $\left(\mathrm{m}^{3} \mu \mathrm{g}^{-1}\right) ; \overline{M W_{\mathrm{OM}}}$ is the estimated average molecular weight of organic compounds $\left(200 \mathrm{~g} \mathrm{~mol}^{-1}\right)$ (Williams et al., 2010; Xie et al., 2014); $p_{\mathrm{L}}^{0}$ is the vapour pressure of pure $\mathrm{H}_{2} \mathrm{O}_{2}$ at the specified temperature, calculated by the extrapolation of the Antoine equation (Maass and Hiebert, 1924; Baum, 1998); $\zeta$ is the activity coefficient of $\mathrm{H}_{2} \mathrm{O}_{2}$, assumed to be unity (Pankow, 1994); $f_{\text {om }}$ is the weight fraction of the organic matter phase in total suspended particulate matter (TSP), also set to unity (Shen et al., 2018); $R$ is the ideal gas constant $\left(8.2 \times 10^{-5} \mathrm{~atm} \mathrm{~m}^{3} \mathrm{~mol}^{-1} \mathrm{~K}^{-1}\right)$; and $T_{\mathrm{W}}$ is the mean temperature during BJ-2018Winter $(270 \pm 4 \mathrm{~K}$ for the whole observation period, $272 \pm 4 \mathrm{~K}$ for daytime, and $269 \pm 4 \mathrm{~K}$ for night-time). In Eq. (4), $C_{\mathrm{p}}^{\mathrm{m}}$ and $C_{\mathrm{g}}^{\mathrm{m}}$ are the concentrations of $\mathrm{H}_{2} \mathrm{O}_{2}$ in the aerosol and gas phases, respectively $\left(\mu \mathrm{g} \mathrm{m}^{-3}\right)$; TSP is the mass concentration of suspended particles $\left(\mathrm{PM}_{2.5}\right.$ is used here, $\left.\mu \mathrm{g} \mathrm{m}^{-3}\right)$; and $K_{\mathrm{P}}^{\mathrm{m}}$ is the effective field-derived gas-aerosol partitioning coefficient $\left(\mathrm{m}^{3} \mu \mathrm{g}^{-1}\right)$. In Eq. (5), $H_{\mathrm{P}}^{\mathrm{m}}$ is the effective field-derived Henry's law constant of $\mathrm{H}_{2} \mathrm{O}_{2}$ for the gas-aerosol phase $\left(\mathrm{M} \mathrm{atm}^{-1}\right)$; and $C_{\mathrm{p}}^{\mathrm{m}}$ (M) and $C_{\mathrm{g}}^{\mathrm{m}}(\mathrm{atm})$ are aerosol- and gas-phase concentrations of $\mathrm{H}_{2} \mathrm{O}_{2}$.

\section{Results and discussion}

\subsection{Gas-liquid phase partitioning}

\subsubsection{Gas- and liquid-phase $\mathrm{H}_{2} \mathrm{O}_{2}$ in summer}

The concentration of gas-phase $\mathrm{H}_{2} \mathrm{O}_{2}$ was measured to be $0.30 \pm 0.26$ parts per billion by volume (ppbv) for the seven rainfall events (Fig. S2a in the Supplement) and $0.53 \pm$ $0.77 \mathrm{ppbv}$ for the entire BJ-2018Summer period. The theoretical liquid-phase $\mathrm{H}_{2} \mathrm{O}_{2}$ value in pure water was $25.20 \mu \mathrm{M}$, and the level of measured $\mathrm{H}_{2} \mathrm{O}_{2}$ in the liquid phase was $44.12 \pm 26.49 \mu \mathrm{M}(3.19-139.95 \mu \mathrm{M})$, as shown in Fig. S2b. The detailed values of the peroxides in the gas and liquid phases are shown in Table S1. Based on Eq. (2), the effective field-derived Henry's law constant, $H_{\mathrm{A}}^{\mathrm{m}}$, averaged $2.1 \times 10^{5} \mathrm{M} \mathrm{atm}^{-1}$ in rain samples, which was 2.5 times the theoretical pure-water Henry's law constant, $H_{\mathrm{A}}^{\mathrm{t}}$, at $8.4 \times$ $10^{4} \mathrm{M} \mathrm{atm}^{-1}$ and $298 \pm 2 \mathrm{~K}$. The average of the ratio of predicted to measured levels of $\mathrm{H}_{2} \mathrm{O}_{2}$ in each rain sample was $88 \%$. The result suggested that $88 \%$ of the measured liquidphase $\mathrm{H}_{2} \mathrm{O}_{2}$ came from gas-phase partitioning, while $12 \%$ of $\mathrm{H}_{2} \mathrm{O}_{2}$ was from other sources. We divided 52 rain samples into three types based on the comparison of the measured and predicted levels of $\mathrm{H}_{2} \mathrm{O}_{2}$. When the difference between levels of the measured and predicted liquid-phase $\mathrm{H}_{2} \mathrm{O}_{2}$ fell within

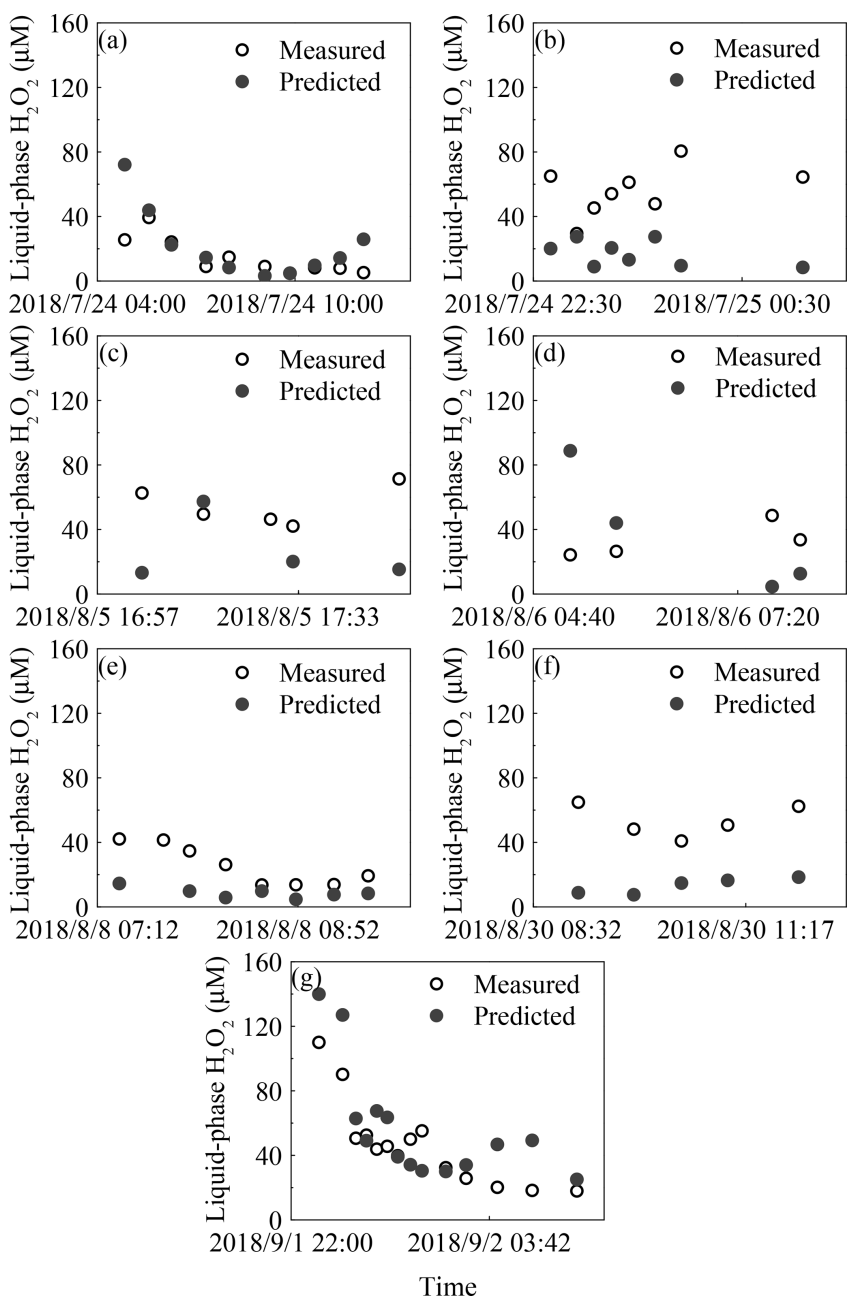

Figure 1. Time profiles of measured and predicted concentrations of $\mathrm{H}_{2} \mathrm{O}_{2}$ from seven rain episodes. The seven rainfall events are listed in chronological order: (a) 24 July, (b) 25 July, (c) 5 August, (d) 6 August, (e) 8 August, (f) 30 August, and (g) 2 September.

$\pm 20 \%$, we suggested that these samples (type B) followed Henry's law, and the remaining samples (types A and C) did not agree with Henry's law. The percentages of samples in types $\mathrm{A}, \mathrm{B}$ and $\mathrm{C}$ were $69 \%, 19 \%$, and $12 \%$, respectively. The details of each rain sample are presented in Fig. 1. In this paper, we focused on the type A samples with a high measured liquid-phase $\mathrm{H}_{2} \mathrm{O}_{2}$ level, and the difference between levels of the measured and predicted liquid-phase $\mathrm{H}_{2} \mathrm{O}_{2}$ averaged $30 \mu \mathrm{M}$ with a maximum of $71 \mu \mathrm{M}$. Further, based on the ratio of the predicted to measured levels of $\mathrm{H}_{2} \mathrm{O}_{2}$ in rainwater, $59 \%$ of the liquid-phase $\mathrm{H}_{2} \mathrm{O}_{2}$ in type A samples was produced from sources other than gas-phase partitioning.

To explain the difference between $H_{\mathrm{A}}^{\mathrm{m}}$ and $H_{\mathrm{A}}^{\mathrm{t}}$, we should rule out the effects of pressure, $\mathrm{pH}$, and $T_{\mathrm{S}}$ on $H_{\mathrm{A}}^{\mathrm{t}}$. First, to our knowledge, the influence of pressure on $H_{\mathrm{A}}^{\mathrm{t}}$ can usually be neglected under conditions of less than $1 \mathrm{~atm}$ (Lind and Kok, 1986). Also, $H_{\mathrm{A}}^{\mathrm{t}}$ of $\mathrm{H}_{2} \mathrm{O}_{2}$ is independent of $\mathrm{pH}$ 
in the range of 4-7 (Xu et al., 2012); therefore, the present study does not consider the influences of pressure and $\mathrm{pH}$ on $H_{\mathrm{A}}^{\mathrm{t}}$. The temperature during BJ-2018Summer could be divided into three ranges: $294-296,297-299$, and 300-306 K. The percentages of samples in these three temperature ranges were $25 \%, 63 \%$, and $12 \%$, respectively, and the ratios of $H_{\mathrm{A}}^{\mathrm{m}}$ to $H_{\mathrm{A}}^{\mathrm{t}}$ in the same temperature ranges were $1.4,2.6$, and 4.5 , respectively. The maximum value of $H_{\mathrm{A}}^{\mathrm{t}}$ in the range $294-306 \mathrm{~K}$ was $1.2 \times 10^{5} \mathrm{M} \mathrm{atm}^{-1}$, while $H_{\mathrm{A}}^{\mathrm{m}}$ reached $4.2 \times 10^{5} \mathrm{M} \mathrm{atm}^{-1}$ at the 90 th percentile. This suggested that the influence of $T_{\mathrm{S}}$ on $H_{\mathrm{A}}^{\mathrm{t}}$ was negligible. The non-linear relationship between $H_{\mathrm{A}}^{\mathrm{m}}$ and $T_{\mathrm{S}}$, shown in Fig. S3, also indicated that $T_{\mathrm{S}}$ played an unimportant role in determining $H_{\mathrm{A}}^{\mathrm{m}}$. Thus, other explanations were needed for understanding the difference between $H_{\mathrm{A}}^{\mathrm{m}}$ and $H_{\mathrm{A}}^{\mathrm{t}}$.

\subsubsection{Process of raindrops falling}

The solubility of $\mathrm{H}_{2} \mathrm{O}_{2}$ in clouds is higher than that in the ground rainwater. There is a negative dependence of the solubility on temperature (Huang and Chen, 2010), which allows for the possibility of mass transfer of $\mathrm{H}_{2} \mathrm{O}_{2}$ from rainwater to the surrounding air when falling. Let us assume that the gas-phase $\mathrm{H}_{2} \mathrm{O}_{2}$ concentration is homogeneous and the rain droplet size remains constant during the falling process. The diameter of the raindrops $\left(D_{\mathrm{P}}\right)$ is mainly distributed in the range of $0.05-2.50 \mathrm{~mm}$. Calculations were performed for typical droplet diameters at $0.1,0.5,1.0$, and $2.0 \mathrm{~mm}$. The height of the precipitation cloud base during summer time in north China was always less than $2000 \mathrm{~m}$ (Shang et al., 2012), so we assumed the fall distance to be 500, 1000, 1500, and $2000 \mathrm{~m}$, respectively, which remained the same as previous studies (Adamowicz, 1979; Levine and Schwartz, 1982). In the process of falling, it was necessary to consider the mass transfer resistance in the gas and liquid phases. However, it could be that the shear force generated on the raindrop surface when it fell improved the mixing rate in the droplet significantly; therefore, the liquid-phase mass transfer resistance was negligible (Pruppacher and Klett, 1997; Elperin and Fominykh, 2005). Thus, the overall mass transfer resistance reduced to the mass transfer resistance in the gas phase.

Here, we first discussed residual $\mathrm{H}_{2} \mathrm{O}_{2}$ in raindrops after a fall from a height of $1000 \mathrm{~m}$. The temperature in clouds $\left(T_{\mathrm{S}}^{\mathrm{c}}\right)$ was estimated to be $292 \mathrm{~K}$, which was $6 \mathrm{~K}$ lower than the ground. $H_{\mathrm{A}}^{\mathrm{t}}$ in pure water at $292 \mathrm{~K}$ was $1.4 \times 10^{5} \mathrm{M} \mathrm{atm}^{-1}$ (Sander et al., 2011). Provided that the droplet started at equilibrium with the cloud atmosphere and the level of $\mathrm{H}_{2} \mathrm{O}_{2}$ in the cloud atmosphere was equal to the level near the ground $\left(0.30 \pm 0.26\right.$ ppbv), the initial level of liquid-phase $\mathrm{H}_{2} \mathrm{O}_{2}$ before falling $\left(C_{\mathrm{aq}}^{0}\right)$ was $42.87 \mu \mathrm{M}$. However, the equilibrium was broken when the raindrops fell as the ambient temperature increased. The mass transfer coefficient in the gas phase $\left(k_{\mathrm{g}}\right)$ can be calculated by Eqs. (S1) to (S4) in the Supplement (Levine and Schwartz, 1982; Kumar, 1985). The concentration of $\mathrm{H}_{2} \mathrm{O}_{2}$ in the droplet at the ground $\left(C_{\mathrm{aq}}^{\mathrm{d}}\right)$ can
Table 1. Calculating the level of $\mathrm{H}_{2} \mathrm{O}_{2}$ in the ground raindrops $\left(C_{\mathrm{aq}}^{\mathrm{d}}\right)$ with different diameters $\left(D_{\mathrm{P}}\right)$ from a height of $1000 \mathrm{~m}^{\mathrm{a}}$.

\begin{tabular}{lrrrr}
\hline Parameters & \multicolumn{4}{c}{$D_{\mathrm{P}}(\mathrm{mm})$} \\
\cline { 2 - 5 } & 0.1 & 0.5 & 1.0 & 2.0 \\
\hline$u\left(\mathrm{~m} \mathrm{~s}^{-1}\right)^{\mathrm{b}}$ & 0.27 & 2.06 & 4.03 & 6.49 \\
$k_{\mathrm{g}}\left(\mathrm{cm} \mathrm{s}^{-1}\right)^{\mathrm{c}}$ & 51.42 & 25.00 & 21.09 & 17.45 \\
$C_{\mathrm{aq}}^{\mathrm{d}}(\mu \mathrm{M})$ & 25.03 & 33.81 & 40.34 & 42.18 \\
\hline
\end{tabular}

a These parameters are calculated based on equations in Gunn and Kinzer (1949), Levine and Schwartz (1982), Kumar (1985), and Seinfeld and Pandis (2006). ${ }^{\mathrm{b}} u$ is the terminal fall velocity of a raindrop. ${ }^{c} k_{\mathrm{g}}$ is the mass transfer coefficient of $\mathrm{H}_{2} \mathrm{O}_{2}$ in the gas phase.

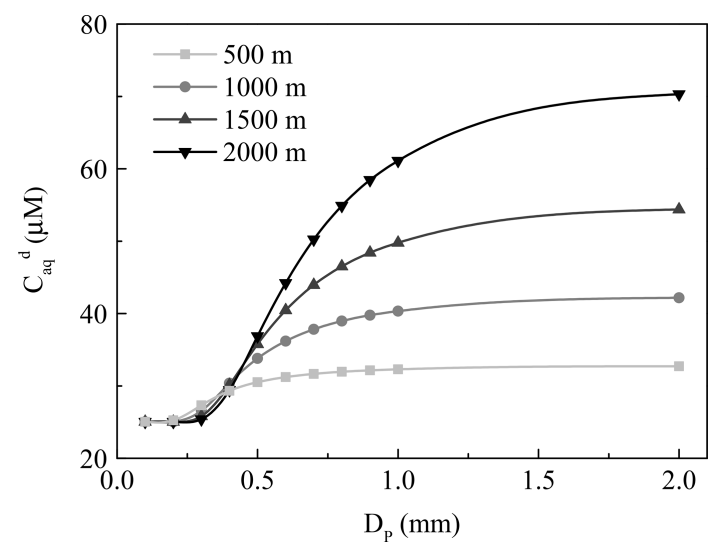

Figure 2. The dependence of the concentration of $\mathrm{H}_{2} \mathrm{O}_{2}$ in the ground raindrops $\left(C_{\mathrm{aq}}^{\mathrm{d}}\right)$ on the diameter of the raindrops $\left(D_{\mathrm{P}}\right)$. The light grey, grey, dark grey, and black lines denote fall distances of $500,1000,1500$, and $2000 \mathrm{~m}$, respectively.

be estimated by Eq. (S5). The results are presented in Table 1, demonstrating that the large droplet has a small mass transfer coefficient. As a result, the liquid-phase $\mathrm{H}_{2} \mathrm{O}_{2}$ in the large raindrops was more slowly released into the air. $C_{\mathrm{aq}}^{\mathrm{d}}$ of the droplet diameter at $2.0 \mathrm{~mm}$ was close to $C_{\mathrm{aq}}^{0}$, while $C_{\mathrm{aq}}^{\mathrm{d}}$ at $0.1 \mathrm{~mm}$ approximated the theoretical level of liquid-phase $\mathrm{H}_{2} \mathrm{O}_{2}$ in pure water at $298 \mathrm{~K}$, as indicated by Fig. 2 . The results demonstrated that the effect of residual $\mathrm{H}_{2} \mathrm{O}_{2}$ in large raindrops on the level of $\mathrm{H}_{2} \mathrm{O}_{2}$ in ground rainwater could be of great importance.

Next, we investigated the influence of different fall distances on $C_{\mathrm{aq}}^{\mathrm{d}}$. The decreasing temperature at increasing fall distances caused larger $H_{\mathrm{A}}^{\mathrm{t}}$ and $C_{\mathrm{aq}}^{0}$ in clouds, and $C_{\mathrm{aq}}^{\mathrm{d}}$ also increased. The wide gap of $C_{\mathrm{aq}}^{\mathrm{d}}$ between different fall distances was more visible for the large droplet, as seen in Fig. 2. Based on the above analysis, the residual $\mathrm{H}_{2} \mathrm{O}_{2}$ in large raindrops could increase the $\mathrm{H}_{2} \mathrm{O}_{2}$ level in rainwater to a maximum of $48.81 \mu \mathrm{M}$ at a fall distance of $2000 \mathrm{~m}$, which could explain to a large extent the difference between the measured and predicted levels of $\mathrm{H}_{2} \mathrm{O}_{2}$ in rainwater. 
Based on the rain intensity, seven rain events during BJ2018Summer could be divided into three types, as shown in Table S2 in the Supplement. Rain events in types I, II, and III have rain intensities $<1,1-10$, and $>10 \mathrm{~mm} \mathrm{~h}^{-1}$, respectively. The larger the diameter of raindrops, the greater the rain intensity (Kumar, 1985). According to the above relationship between the diameter of raindrops and the level of liquid-phase $\mathrm{H}_{2} \mathrm{O}_{2}$ in the ground rainwater, the difference between the measured and predicted liquid-phase $\mathrm{H}_{2} \mathrm{O}_{2}$ levels should be greater as the hourly rain intensity increases. We found that the differences between $C_{\mathrm{aq}}^{\mathrm{m}}$ and $C_{\mathrm{aq}}^{\mathrm{t}}$ increased during the rain periods on 25 July and 5 August, during which the maximum hourly rain intensities were more than $10 \mathrm{~mm} \mathrm{~h}^{-1}$. Because it is difficult for the liquid-phase $\mathrm{H}_{2} \mathrm{O}_{2}$ in heavy rains to diffuse into the gas phase, much $\mathrm{H}_{2} \mathrm{O}_{2}$ may be retained in the ground rainwater, which could well represent the level of $\mathrm{H}_{2} \mathrm{O}_{2}$ in cloud water.

During the rain episode on 1-2 September 2018, the concentration of gas-phase $\mathrm{H}_{2} \mathrm{O}_{2}$ decreased over time. However, there was a sudden rise from $0.47 \mathrm{ppbv}$ at 01:03 local time (LT) to $0.66 \mathrm{ppbv}$ at $01: 46 \mathrm{LT}$, which subsequently dropped to $0.38 \mathrm{ppbv}$ over time (Fig. 3a). Surprisingly, the difference between the measured and predicted levels of liquid-phase $\mathrm{H}_{2} \mathrm{O}_{2}$ reached a low value in the meantime, indicating that the increase in gas-phase $\mathrm{H}_{2} \mathrm{O}_{2}$ was due to the release of $\mathrm{H}_{2} \mathrm{O}_{2}$ from raindrops that contained high level of $\mathrm{H}_{2} \mathrm{O}_{2}$, as presented in Fig. 3b. Compared with Fig. S4 in the Supplement, which described the relationship between rain intensity and time, the rain intensity simultaneously dropped to $3.51 \mathrm{~mm} \mathrm{~h}^{-1}$ from $6.35 \mathrm{~mm} \mathrm{~h}^{-1}$, consequently decreasing the diameter of the raindrops and increasing the mass transfer of $\mathrm{H}_{2} \mathrm{O}_{2}$ from rainwater to the gas phase. Provided that $20 \mu \mathrm{M} \mathrm{H}_{2} \mathrm{O}_{2}$ in rainwater was released into ambient air, the increase in the gas-phase $\mathrm{H}_{2} \mathrm{O}_{2}$ level was $0.24 \mathrm{ppbv}$, which was in accordance with the sudden rise during 01:0301:46 LT on 1-2 September 2018.

The above analysis assumes that the gas-phase $\mathrm{H}_{2} \mathrm{O}_{2}$ concentration is uniform. However, the distribution of gas-phase $\mathrm{H}_{2} \mathrm{O}_{2}$ at different heights may be complicated. We could use the average level of $\mathrm{H}_{2} \mathrm{O}_{2}$ in rainwater at the ground to estimate the concentrations of $\mathrm{H}_{2} \mathrm{O}_{2}$ in cloud water $\left(C_{\mathrm{aq}}^{\mathrm{c}}\right)$ and the nearby atmosphere $\left(C_{\mathrm{g}}^{\mathrm{c}}\right)$, as presented in Table 2. Assuming the simplest case, $D_{\mathrm{P}}$ is $1.0 \mathrm{~mm}$, the fall distance is $1000 \mathrm{~m}$, and the levels of $\mathrm{H}_{2} \mathrm{O}_{2}$ in the gas phase and rainwater at the ground are $0.30 \mathrm{ppbv}$ and $44.12 \mu \mathrm{M}$ at $298 \mathrm{~K}$, respectively. Considering the release of $\mathrm{H}_{2} \mathrm{O}_{2}$ from raindrops into ambient air during the falling process, the level of $\mathrm{H}_{2} \mathrm{O}_{2}$ in cloud water should be $47 \mu \mathrm{M}$. Based on Henry's law, the surrounding gas-phase $\mathrm{H}_{2} \mathrm{O}_{2}$ should be 0.33 ppbv, a little higher than that at the ground. When the fall distance is 500, 1500, and $2000 \mathrm{~m}, \mathrm{H}_{2} \mathrm{O}_{2}$ in cloud water should be 46,49 , and $51 \mu \mathrm{M}$, respectively, and $\mathrm{H}_{2} \mathrm{O}_{2}$ in nearby ambient air could be 0.41 , 0.26 , and $0.21 \mathrm{ppbv}$, respectively.

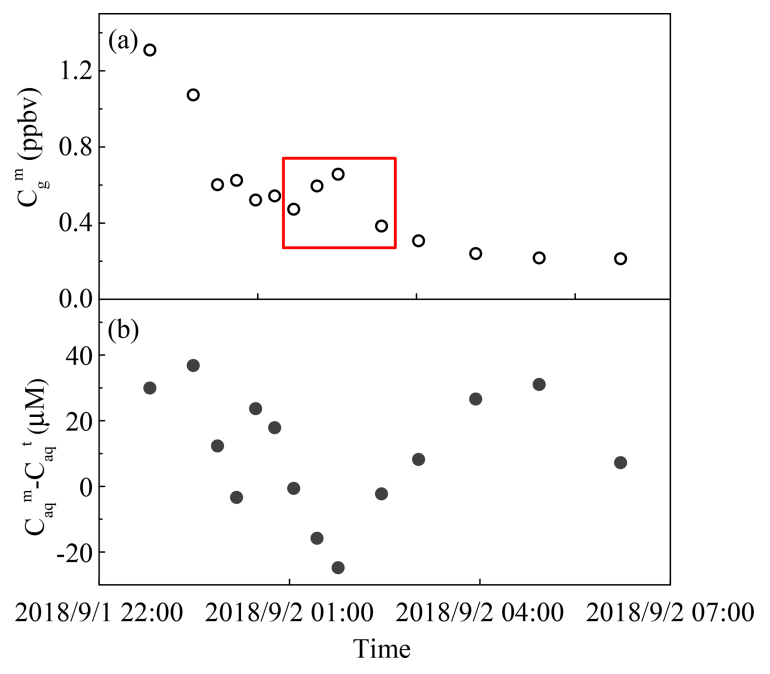

Figure 3. The measured and predicted $\mathrm{H}_{2} \mathrm{O}_{2}$ levels in a rain event on 1-2 September 2018. (a) Measured gas-phase $\mathrm{H}_{2} \mathrm{O}_{2}\left(C_{\mathrm{g}}^{\mathrm{m}}\right)$. (b) The difference between measured $\left(C_{\mathrm{aq}}^{\mathrm{m}}\right)$ and theoretical $\left(C_{\mathrm{aq}}^{\mathrm{t}}\right)$ levels of $\mathrm{H}_{2} \mathrm{O}_{2}$ in the liquid phase. The red box indicates a sudden rise in gas-phase $\mathrm{H}_{2} \mathrm{O}_{2}$.

Table 2. Estimates of the level of $\mathrm{H}_{2} \mathrm{O}_{2}$ in cloud water $\left(C_{\mathrm{aq}}^{\mathrm{c}}\right)$ and the surrounding atmosphere $\left(C_{\mathrm{g}}^{\mathrm{c}}\right)$ at different fall distances with a raindrop diameter of $1.0 \mathrm{~mm}$.

\begin{tabular}{lrrrr}
\hline Parameters & $500 \mathrm{~m}$ & $1000 \mathrm{~m}$ & $1500 \mathrm{~m}$ & $2000 \mathrm{~m}$ \\
\hline$T_{\mathrm{S}}^{\mathrm{c}}(\mathrm{K})^{*}$ & 295 & 292 & 289 & 286 \\
$H_{\mathrm{A}}^{\mathrm{t}}\left(\mathrm{M} \mathrm{atm}^{-1}\right)$ & $1.1 \times 10^{5}$ & $1.4 \times 10^{5}$ & $1.9 \times 10^{5}$ & $2.5 \times 10^{5}$ \\
$C_{\mathrm{aq}}^{\mathrm{c}}(\mu \mathrm{M})$ & 45.64 & 47.27 & 49.04 & 50.95 \\
$C_{\mathrm{g}}^{\mathrm{c}}(\mathrm{ppbv})$ & 0.41 & 0.33 & 0.26 & 0.21 \\
\hline
\end{tabular}

${ }^{*} T_{\mathrm{S}}^{\mathrm{c}}$ is the temperature in cloud water.

\subsection{Gas-aerosol phase partitioning}

\subsubsection{Gas- and aerosol-phase $\mathrm{H}_{2} \mathrm{O}_{2}$ in winter}

From 21 December 2018 to 5 January 2019, the gas-phase $\mathrm{H}_{2} \mathrm{O}_{2}$ level was $24.08 \pm 28.83$ pptv, as shown in Fig. S5a in the Supplement. We eluted Teflon filters with $\mathrm{H}_{3} \mathrm{PO}_{4}$ solution and measured the level of $\mathrm{H}_{2} \mathrm{O}_{2}$ in the extracted solution to calculate the aerosol-phase $\mathrm{H}_{2} \mathrm{O}_{2}$ concentration. The mass concentration of aerosol-phase $\mathrm{H}_{2} \mathrm{O}_{2}$ and the normalized concentration to aerosol mass were $2.22 \pm 1.49 \mathrm{ng} \mathrm{m}^{-3}$ $\left(\mathrm{DL}-6.75 \mathrm{ng} \mathrm{m}^{-3}\right.$ ) and $0.093 \pm 0.085 \mathrm{ng} \mathrm{g}^{-1}$ (DL -

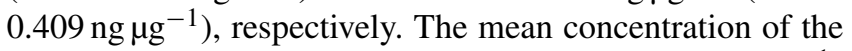
aerosol-phase $\mathrm{H}_{2} \mathrm{O}_{2}$ at night-time $\left(0.107 \pm 0.102 \mathrm{ng} \mathrm{\mu g}^{-1}\right)$ was higher than that at daytime $\left(0.079 \pm 0.066 \mathrm{ng} \mathrm{\mu g}^{-1}\right)$, as presented in Fig. S5b. The level of aerosol-phase $\mathrm{H}_{2} \mathrm{O}_{2}$ in the present study was lower than those reported in previous studies (Table S3), which may be due to the extraction method, the extraction time, reducing substance levels, or aerosol $\mathrm{pH}$ 
value, as shown in the Supplement. Assuming a molecular weight of $300 \mathrm{~g} \mathrm{~mol}^{-1}$ (Docherty et al., 2005; Epstein et al., 2014), the level of TPOs averaged $10.26 \pm 6.38 \mathrm{ng} \mathrm{\mu g}^{-1}$ (2.08-28.75 ng $\left.\mu \mathrm{g}^{-1}\right)$. It was calculated that $\mathrm{H}_{2} \mathrm{O}_{2}$ took up a small fraction of TPOs, equal to $8 \pm 6 \%$ in molar concentration ratio, which indicated that organic peroxides accounted for a large proportion of peroxides and could play important roles in the formation of $\mathrm{PM}_{2.5}$ and secondary organic aerosols.

The measured level of $\mathrm{H}_{2} \mathrm{O}_{2}$ in aerosols was much higher than the predicted value using Pankow's absorptive partitioning theory, which suggested that the aerosols collected on the filter existed under non-equilibrium conditions, and the aerosol-phase $\mathrm{H}_{2} \mathrm{O}_{2}$ may arise from sources other than gasphase partitioning. Based on Eqs. (3) and (4), $K_{\mathrm{P}}^{\mathrm{m}}$ was equal to $3.8 \times 10^{-3} \pm 4.8 \times 10^{-3} \mathrm{~m}^{3} \mu \mathrm{g}^{-1}$ at $270 \pm 4 \mathrm{~K}$, which was 4 orders of magnitude higher than $K_{\mathrm{P}}^{\mathrm{t}}, 2.8 \times 10^{-7} \mathrm{~m}^{3} \mu \mathrm{g}^{-1}$. The effect of parameter variation on calculating $K_{\mathrm{P}}^{\mathrm{t}}$ could not account for the large discrepancy between $K_{\mathrm{P}}^{\mathrm{m}}$ and $K_{\mathrm{P}}^{\mathrm{t}}$ (Shen et al., 2018), and other factors are needed to explain the difference. In terms of the proportion of theoretical to measured concentrations, the partitioning of gas-phase $\mathrm{H}_{2} \mathrm{O}_{2}$ into aerosols could be neglected, and nearly all of the aerosolphase $\mathrm{H}_{2} \mathrm{O}_{2}$ was generated from other reactions.

Because aerosol water content (AWC) cannot be correctly evaluated at low $\mathrm{RH}$, the effective field-derived Henry's law constant $\left(\mathrm{H}_{\mathrm{P}}^{\mathrm{m}}\right)$ of $\mathrm{H}_{2} \mathrm{O}_{2}$ was estimated for the high- $\mathrm{RH}$ condition, e.g. a heavy haze episode from 2 to 3 January 2019 (RH, $30 \%$ ). Details regarding the estimation of AWC are shown in the Supplement. It was calculated that AWC, $C_{\mathrm{p}}^{\mathrm{m}}$, and $C_{\mathrm{g}}^{\mathrm{m}}$ levels averaged $3.20 \mu \mathrm{g} \mathrm{m}^{-3}, 6.63 \times 10^{3} \mu \mathrm{M}$, and $1.90 \times 10^{-11}$ atm. Based on Eq. (5), the average $H_{\mathrm{P}}^{\mathrm{m}}$ on 2-3 January 2019 was calculated to be $2.7 \times 10^{8} \pm 1.8 \times$ $10^{8} \mathrm{M} \mathrm{atm}^{-1}$. However, the theoretical Henry's law constant $\left(H_{\mathrm{P}}^{\mathrm{t}}\right)$ at $270 \mathrm{~K}$ was $1.1 \times 10^{6} \mathrm{M} \mathrm{atm}^{-1}$ (Sander et al., 2011), which was lower than $H_{\mathrm{P}}^{\mathrm{m}}$ by 2 orders of magnitude. In the study of Chung et al. (2005), the salting-in effect can improve the level of $\mathrm{H}_{2} \mathrm{O}_{2}$ by a factor of 2 when the concentrations in salt solutions were up to $10 \mathrm{M}$, and the most obvious salting-in effect of salt solutions was ammonium sulfate. In this paper, the levels of aerosol-phase $\mathrm{NH}_{4}^{+}$and $\mathrm{SO}_{4}^{2-}$ on 2-3 January 2019 were 94 and $21 \mathrm{M}$, respectively, and the level of $\left(\mathrm{NH}_{4}\right)_{2} \mathrm{SO}_{4}$ was assumed to be $21 \mathrm{M}$. The increase of $H_{\mathrm{P}}^{\mathrm{m}}$ by the salting-in effect of $\left(\mathrm{NH}_{4}\right)_{2} \mathrm{SO}_{4}$ was about $3.2 \times 10^{6} \mathrm{M} \mathrm{atm}^{-1}$ at $286 \mathrm{~K}$ based on equations in Chung et al. (2005). Even though aerosol particles were collected at $270 \pm 4 \mathrm{~K}$ and the increase may be greater, the salting-in effect could not fully explain the difference between $H_{\mathrm{P}}^{\mathrm{m}}$ and $H_{\mathrm{P}}^{\mathrm{t}}$. Other sources need to be found later.

\subsubsection{Factor analysis}

Figure 4 demonstrates that the concentration of aerosolphase $\mathrm{H}_{2} \mathrm{O}_{2}$ is dependent on $\mathrm{RH}$, with a trend that is first increasing (stage A) and then decreasing (stage B) as $\mathrm{RH}$

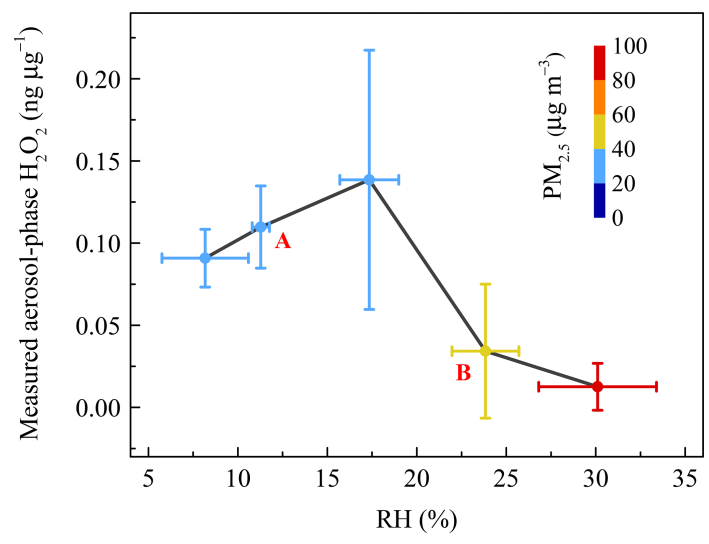

Figure 4. The relationship between measured aerosol-phase $\mathrm{H}_{2} \mathrm{O}_{2}$ level and relative humidity (RH). Coloured circles denote the mass concentration of $\mathrm{PM}_{2.5}$. The vertical error bars represent the standard deviations of aerosol-phase $\mathrm{H}_{2} \mathrm{O}_{2}$ concentration in every $\mathrm{RH}$ range bin. $\mathrm{A}$ and $\mathrm{B}$ refer to the increase and decrease stages, respectively.

increases. The variation of $\mathrm{H}_{2} \mathrm{O}_{2}$ with $\mathrm{RH}$ was the result of competition between production and consumption processes. Here, the production process refers to either process that favours increasing the level of aerosol-phase $\mathrm{H}_{2} \mathrm{O}_{2}$, while the consumption process refers to the process consuming aerosol-phase $\mathrm{H}_{2} \mathrm{O}_{2}$. In the first stage, the higher $\mathrm{RH}$ could accelerate the heterogeneous uptake of $\mathrm{H}_{2} \mathrm{O}_{2}$ onto aerosols and enhance the level of aerosol-phase $\mathrm{H}_{2} \mathrm{O}_{2}$ (Pradhan et al., 2010; Shiraiwa et al., 2011; Zhao et al., 2013; Slade and Knopf, 2015). The level of $\mathrm{H}_{2} \mathrm{O}_{2}$ was negatively associated with $\mathrm{RH}$ in the subsequent stage, ascribed to much more rapid consumption of $\mathrm{H}_{2} \mathrm{O}_{2}$ due to its oxidizing of the reducing substances on polluted days, such as $\mathrm{SO}_{2}$ into $\mathrm{SO}_{4}^{2-}$.

We considered a heavy haze episode, from 2 to 3 January 2019 , as an example to explain the important contribution of aerosol-phase $\mathrm{H}_{2} \mathrm{O}_{2}$ to $\mathrm{SO}_{4}^{2-}$ growth on polluted days in detail. The $\mathrm{PM}_{2.5}$ mass concentration of the severe haze event was up to $201.20 \mu \mathrm{g} \mathrm{m}^{-3}$. Based on the measured $\mathrm{H}_{2} \mathrm{O}_{2}$, the reaction rate $(\mathrm{RR})$ and sulfate formation rate $(\mathrm{SFR})$ averaged about $3.03 \times 10^{-3} \mu \mathrm{mol} \mathrm{m}{ }^{-3} \mathrm{~h}^{-1}$ and $0.29 \mu \mathrm{g} \mathrm{m}^{-3} \mathrm{~h}^{-1}$ (Table S4), respectively. The detailed calculation process is provided in the Supplement. In addition, the growth rate of $\mathrm{SO}_{4}^{2-}$ calculated by the measured data was $0.51 \mu \mathrm{g} \mathrm{m}^{-3} \mathrm{~h}^{-1}$, and $\mathrm{H}_{2} \mathrm{O}_{2}$ oxidation pathway contributed about $57 \%$ of the measured growth of $\mathrm{SO}_{4}^{2-}$ in $\mathrm{PM}_{2.5}$. This result strongly suggested that the aerosol-phase $\mathrm{H}_{2} \mathrm{O}_{2}$ indeed acted as an important oxidant in the formation of sulfate, and played significant roles in the rapid growth of $\mathrm{PM}_{2.5}$ during pollution events.

Next, we considered that the consumption rate of aerosolphase $\mathrm{H}_{2} \mathrm{O}_{2}$ increased with an increase of $\mathrm{RH}$. The extent of the concentration variations of $\mathrm{H}_{2} \mathrm{O}_{2}, \mathrm{SO}_{4}^{2-}$, and $\mathrm{PM}_{2.5}$ at 10 th and 90th percentiles were 22, 6, and 5, respectively, suggesting that the inverse relationship still existed when we eliminated the interference of the dilution effect due to a 


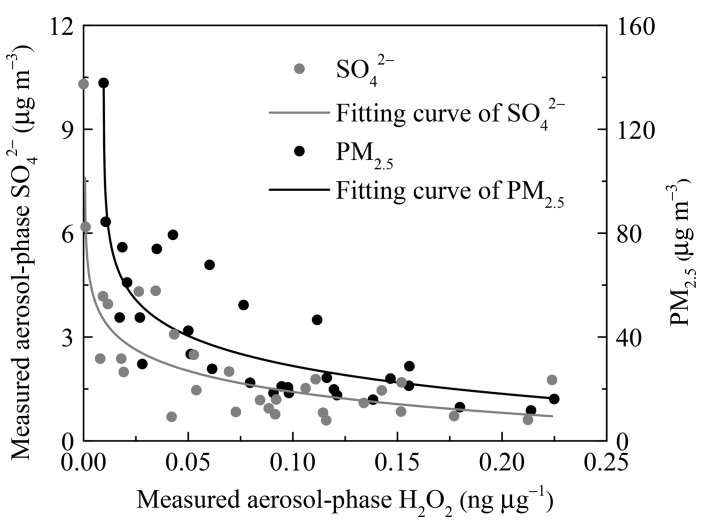

Figure 5. The negative dependence of the measured concentrations of aerosol-phase $\mathrm{SO}_{4}^{2-}$ and $\mathrm{PM}_{2.5}$ on $\mathrm{H}_{2} \mathrm{O}_{2}$. The grey and black lines are the logarithmic fits for $\mathrm{SO}_{4}^{2-}$ level in aerosols and the $\mathrm{PM}_{2.5}$ mass concentration, respectively.

high aerosol loading. The dilution effect was unimportant and could be neglected. It is suggested that larger levels of $\mathrm{SO}_{4}^{2-}$ and $\mathrm{PM}_{2.5}$ are often accompanied by higher $\mathrm{RH}$. In Fig. 5, the reverse curve between aerosol-phase $\mathrm{SO}_{4}^{2-}$ and $\mathrm{H}_{2} \mathrm{O}_{2}$ became steeper with the formation of $\mathrm{SO}_{4}^{2-}$, indicating that the rate of consumption of $\mathrm{H}_{2} \mathrm{O}_{2}$ on polluted days was much higher than that on clean days, which could offer proof of rapid $\mathrm{H}_{2} \mathrm{O}_{2}$ consumption with increasing $\mathrm{RH}$. In addition, the level of $\mathrm{H}_{2} \mathrm{O}_{2}$ in the aerosol phase exhibited a negative correlation with $\mathrm{PM}_{2.5}$ mass concentration, as shown in Fig. 5. In other words, the aerosol-phase $\mathrm{H}_{2} \mathrm{O}_{2}$ concentration was lower on polluted days than on clean days, further demonstrating that the removal rate of $\mathrm{H}_{2} \mathrm{O}_{2}$ by oxidizing $\mathrm{SO}_{2}$ into $\mathrm{SO}_{4}^{2-}$ exceeded the production rate during pollution events with high $\mathrm{RH}$.

\subsubsection{Heterogeneous uptake of $\mathrm{H}_{2} \mathrm{O}_{2}$ and $\mathrm{HO}_{2}$}

In addition to the factors that influence the aerosol-phase $\mathrm{H}_{2} \mathrm{O}_{2}$ concentration, there are certain physical and chemical reactions other than gas-phase partitioning that could increase the level of aerosol-phase $\mathrm{H}_{2} \mathrm{O}_{2}$, e.g. heterogeneous uptake of $\mathrm{H}_{2} \mathrm{O}_{2}$ on aerosols. Previous studies have shown that heterogeneous uptake of $\mathrm{H}_{2} \mathrm{O}_{2}$ is positively related to $\mathrm{RH}$. High $\mathrm{RH}$ is beneficial to the mass transfer of $\mathrm{H}_{2} \mathrm{O}_{2}$ from the gas phase to the aerosol phase, which could accelerate the reaction between $\mathrm{H}_{2} \mathrm{O}_{2}$ and reducing compositions of aerosols, thus contributing to more heterogeneous uptake of $\mathrm{H}_{2} \mathrm{O}_{2}$ (Huang et al., 2015; Wu et al., 2015). To quantitatively evaluate the importance of the heterogeneous uptake of $\mathrm{H}_{2} \mathrm{O}_{2}$ on aerosols to the aerosol-phase $\mathrm{H}_{2} \mathrm{O}_{2}$, we calculated the average rate of heterogeneous uptake based on Eqs. (S6) to (S11) in the Supplement. Details about each parameter were introduced in Table 3, and the heterogeneous uptake rate of $\mathrm{H}_{2} \mathrm{O}_{2}\left(\mathrm{~d}[X]_{\mathrm{p}}^{\mathrm{t}, \mathrm{h}} / \mathrm{d} t\right)$ averaged $0.02 \mathrm{ng} \mathrm{\mu g}^{-1} \mathrm{~h}^{-1}$.
As $\mathrm{HO}_{2}$ radical is a precursor of $\mathrm{H}_{2} \mathrm{O}_{2}$, the heterogeneous uptake of $\mathrm{HO}_{2}$ onto aerosols may also contribute to the formation of the aerosol-phase $\mathrm{H}_{2} \mathrm{O}_{2}$. We assumed that the reactive uptake coefficient of $\mathrm{HO}_{2}$ to aerosol particles was 0.2 , and the product of $\mathrm{HO}_{2}$ was $\mathrm{H}_{2} \mathrm{O}_{2}$ ( $\mathrm{Li}$ et al., 2019). At the same observation site in winter of $2017, \mathrm{HO}_{2}$ concentration for noontime averaged $(0.4 \pm 0.2) \times 10^{8}$ and $(0.3 \pm 0.2) \times 10^{8} \mathrm{~cm}^{-3}$ on clean and polluted days, respectively (Ma et al., 2019). Since $\mathrm{HO}_{2}$ level data in 2018 was not available, we used the level of $\mathrm{HO}_{2}$ on clean days in winter of 2017 for calculations, and the average was about $0.2 \times 10^{8} \mathrm{~cm}^{-3}$ at daytime. The heterogeneous uptake rate of $\mathrm{HO}_{2}$ on aerosols was calculated in the same way as $\mathrm{H}_{2} \mathrm{O}_{2}$, and the formation rate of the aerosol-phase $\mathrm{H}_{2} \mathrm{O}_{2}$ by reactive uptake of $\mathrm{HO}_{2}$ averaged $0.22 \mathrm{ng} \mathrm{\mu g}^{-1} \mathrm{~h}^{-1}$ all day.

\subsubsection{Decomposition of organic peroxides}

It was demonstrated that the concentration of $\mathrm{H}_{2} \mathrm{O}_{2}$ in the extracted solution first increased rapidly, then reached peaks at distinct hours that depended on the specific sample, and finally declined gradually over time. However, interestingly, there was large sample-to-sample variation, with samples classifiable into three types in terms of the change in trend and evolution duration (Fig. 6 and Table 4). The third type (Fig. 6c) occurred when the $\mathrm{H}_{2} \mathrm{O}_{2}$ level exhibited a steady decline without a growth stage within $13 \mathrm{~h}$, and this was the case with samples 5 and 6 on a slightly polluted day on 2 January 2019. Samples 1 and 2 on 29 December 2018 during clean days belonged to the first type (Fig. 6a), during which $\mathrm{H}_{2} \mathrm{O}_{2}$ rapidly grew within $5 \mathrm{~h}$ and subsequently decreased at a slow rate over $25 \mathrm{~h}$. The evolution trends of $\mathrm{H}_{2} \mathrm{O}_{2}$ in the second type (samples 3 and 4, Fig. 6b) during clean days from 31 December 2018 to 1 January 2019 were similar to those of the first type, except $\mathrm{H}_{2} \mathrm{O}_{2}$ approached its peak at about $40 \mathrm{~h}$ over the whole analysis process lasting for about $300 \mathrm{~h}$. Given that the $\mathrm{H}_{2} \mathrm{O}_{2}$ concentration increased in the extracted solution as time went, the effects of the extraction and transportation processes on the effective gas-aerosol partitioning coefficient of $\mathrm{H}_{2} \mathrm{O}_{2}$ were discussed, as shown in the Supplement.

To seek the reasons for the elevated level of $\mathrm{H}_{2} \mathrm{O}_{2}$ in the extracted solution, we compared the ratio of the maximum $\left(C_{\max }\right)$ to initial $\left(C_{0}\right) \mathrm{H}_{2} \mathrm{O}_{2}$ concentrations in the extracted solution with the molar concentration ratio of the aerosolphase TPOs to $\mathrm{H}_{2} \mathrm{O}_{2}$ and found that the ratios of $C_{\max } / C_{0}$ and TPOs $/ \mathrm{H}_{2} \mathrm{O}_{2}$ were in the same order of magnitude for the first and second types, as exhibited in Table S5 in the Supplement. This result provided evidence that part of the aerosolphase $\mathrm{H}_{2} \mathrm{O}_{2}$ originated from the decomposition/hydrolysis of organic peroxides, as described in earlier studies (Wang et al., 2011; Li et al., 2016). In the second type, the concentration of TPOs normalized to aerosol mass reached a maximum, indicating that the second type had more TPO sources, which consequently caused higher TPOs $/ \mathrm{H}_{2} \mathrm{O}_{2}$ and $C_{\max } / C_{0}$ ra- 
Table 3. Calculating the theoretical heterogeneous uptake rate of $\mathrm{H}_{2} \mathrm{O}_{2}$ on aerosols $\left(\mathrm{d}[X]_{\mathrm{p}}^{\mathrm{t}, \mathrm{h}} / \mathrm{d} t\right)^{\mathrm{a}}$.

\begin{tabular}{lrrrrrr}
\hline Parameters & $\begin{array}{r}T_{\mathrm{W}} \\
(\mathrm{K})\end{array}$ & $\begin{array}{r}\mathrm{RH} \\
(\%)\end{array}$ & $\begin{array}{r}\gamma \\
(-)^{\mathrm{b}}\end{array}$ & $\begin{array}{r}S_{\mathrm{aw}} \\
\left(\mathrm{cm}^{2}\right)^{\mathrm{c}}\end{array}$ & $\begin{array}{r}{[X]_{\mathrm{g}}} \\
\left(\text { molecules m}^{-3}\right)^{\mathrm{d}}\end{array}$ & $\begin{array}{r}\mathrm{d}[X]_{\mathrm{p}}^{\mathrm{t}, \mathrm{h}} / \mathrm{d} t \\
\left(\mathrm{ng} \mu \mathrm{g}^{-1} \mathrm{~h}^{-1}\right)\end{array}$ \\
\hline Averages & 270 & 17.89 & $1.54 \times 10^{-4}$ & 46 & $6.54 \times 10^{14}$ & 0.02 \\
\hline
\end{tabular}

${ }^{\mathrm{a}}$ These parameters are calculated based on Wu et al. (2015). ${ }^{\mathrm{b}} \gamma$ is the heterogeneous uptake coefficient (dimensionless).

${ }^{c} S_{\text {aw }}$ is the surface area of aerosols, quoted from Kuang et al. (2019). ${ }^{\mathrm{d}}[X] \mathrm{g}$ is the concentration of gas-phase $\mathrm{H}_{2} \mathrm{O}_{2}$.
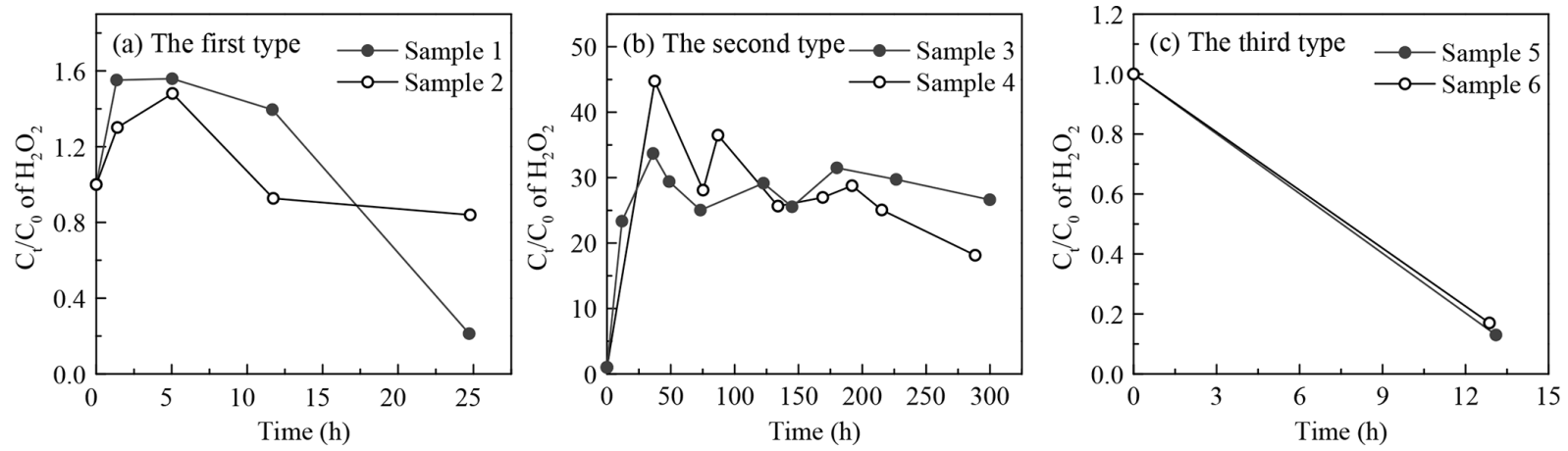

Figure 6. Time profiles of aerosol-phase $\mathrm{H}_{2} \mathrm{O}_{2}$ evolution in the extracted solution. (a) The first type: samples 1 and 2 were collected on 29 December 2018. (b) The second type: samples 3 and 4 were gathered on 31 December 2018-1 January 2019. (c) The third type: samples 5 and 6 were collected on 2 January 2019. $C_{t}$ and $C_{0}$ denote molar concentrations of $\mathrm{H}_{2} \mathrm{O}_{2}$ in the extracted solution at time $=t$ and time $=0$.

Table 4. Comparison of the $\mathrm{H}_{2} \mathrm{O}_{2}$ evolution parameters in the extracted solution among the three types.

\begin{tabular}{|c|c|c|c|}
\hline Parameters & $\begin{array}{l}\text { First } \\
\text { type }\end{array}$ & $\begin{array}{r}\text { Second } \\
\text { type }\end{array}$ & $\begin{array}{r}\text { Third } \\
\text { type }\end{array}$ \\
\hline Peak time (h) & 5 & 40 & - \\
\hline $\begin{array}{l}\text { Decomposition rate of organic } \\
\text { peroxides to } \mathrm{H}_{2} \mathrm{O}_{2}\left(\mathrm{ng} \mathrm{\mu g}^{-1} \mathrm{~h}^{-1}\right)\end{array}$ & 0.01 & 0.10 & - \\
\hline$C_{\max } / C_{0}$ of $\mathrm{H}_{2} \mathrm{O}_{2}\left(\mu \mathrm{M} \mu \mathrm{M}^{-1}\right)$ & 1.52 & 39.22 & 1.00 \\
\hline TPOs $/ \mathrm{H}_{2} \mathrm{O}_{2}\left(\mu \mathrm{M} \mu \mathrm{M}^{-1}\right)$ & 5.25 & 40.06 & 47.59 \\
\hline $\begin{array}{l}\text { Ratio of decomposable organic } \\
\text { peroxides }(\%)\end{array}$ & 29 & 98 & 0 \\
\hline
\end{tabular}

tios compared with the first type. Furthermore, the aerosol surface is semi-liquid or liquid under high RH (Liu et al., 2017), which provides reaction sites for the decomposition/hydrolysis of aerosol-phase organic peroxides. Aerosolphase organic peroxides could decompose into $\mathrm{H}_{2} \mathrm{O}_{2}$ before the particle aerosols were collected (Zhao et al., 2018). Thus, the decomposition/hydrolysis of organic peroxides in the extracted solution could be applied to the ambient particles. The average rates of the decomposition/hydrolysis of organic peroxides to $\mathrm{H}_{2} \mathrm{O}_{2}$ in the rising stage for the first and second types were 0.01 and $0.10 \mathrm{ng} \mathrm{\mu g}^{-1} \mathrm{~h}^{-1}$, respectively.
The three types of samples were in accordance with the growth process of $\mathrm{PM}_{2.5}$. According to meteorological parameters and trace-gas data (Table S6 in the Supplement), static weather conditions gradually formed and were accompanied by lower wind speed, lower ozone level, higher $\mathrm{RH}$, and higher gaseous pollutants levels. The mass concentration of $\mathrm{PM}_{2.5}$ increased from 13.45 to $63.11 \mu \mathrm{g} \mathrm{m}^{-3}$. In addition, the mass concentration of TPOs also showed a rising trend, whereas the level of TPOs normalized to aerosol mass increased at first and decreased afterwards due to the rapid growth of $\mathrm{PM}_{2.5}$. Because of the consumption of reactive TPOs, which formed $\mathrm{SO}_{4}^{2-}$ during polluted days, the rest of the TPOs were stable organic peroxides that could not easily decompose into $\mathrm{H}_{2} \mathrm{O}_{2}$, e.g. peroxide esters (ROOR). The ratio of TPOs $/ \mathrm{H}_{2} \mathrm{O}_{2}$ in the third type, collected on a slightly polluted day, was close to that in the second type on clean days, but a rising trend of $\mathrm{H}_{2} \mathrm{O}_{2}$ in the extracted solution could not be observed. It was calculated that the ratios of decomposable TPOs to total TPOs for the three types were $29 \%, 98 \%$, and $0 \%$, respectively.

Recently, it was reported that organic peroxides accounted for a large proportion of secondary organic aerosol (SOA) mass, varying widely from less than $20 \%$ to $60 \%$ (Docherty et al., 2005; Li et al., 2016; Gong et al., 2018). Peroxy radicals also played important parts in the formation of highly oxygenated molecules (HOMs) via an autoxidation mechanism, which can form aerosols without sulfuric acid nucleation (Kirkby et al., 2016). The thermal decomposition of 
peroxide-containing SOAs and HOMs contributed to the formation of aerosol-phase $\mathrm{H}_{2} \mathrm{O}_{2}$ (Krapf et al., 2016). A similar phenomenon was also found by $\mathrm{Li}$ et al. (2016), in which the decomposition/hydrolysis of organic peroxides sustainably generated $\mathrm{H}_{2} \mathrm{O}_{2}$ accompanied by the attenuation of TPOs in the extracted solution, and about $18 \%$ of gaseous organic peroxides underwent the heterogeneous decomposition on aerosols into $\mathrm{H}_{2} \mathrm{O}_{2}$. The decomposable organic peroxides are often peroxycarboxylic acids (PCAs, e.g. peroxyacetic acid, PAA; peroxyformic acid, PFA) and $\alpha$-hydroxyalkylhydroperoxides ( $\alpha$-HAHPs, e.g. hydroxymethyl hydroperoxide, HMHP).

\subsection{Source and sink of $\mathrm{H}_{2} \mathrm{O}_{2}$ in rainwater and aerosols}

To provide support for the sources suggested above, we analysed the sources and sinks of liquid- and aerosol-phase $\mathrm{H}_{2} \mathrm{O}_{2}$ in rainwater and aerosols. In this study, the measured level of $\mathrm{H}_{2} \mathrm{O}_{2}$ was the concentration after partial or complete reaction with reducing substances, such as $\mathrm{SO}_{2}$ onto the particles. The contribution of different additional sources in the liquid and aerosol phases should be estimated compared with the important sink.

The level of liquid-phase $\mathrm{H}_{2} \mathrm{O}_{2}$ was the result of the combined effect between sources (gas-phase partitioning and residual $\mathrm{H}_{2} \mathrm{O}_{2}$ in raindrops) and sinks (reaction with $\mathrm{S}(\mathrm{IV}$ ) and the decomposition of $\mathrm{H}_{2} \mathrm{O}_{2}$ ). Based on the foregoing description, the dissolved gas-phase $\mathrm{H}_{2} \mathrm{O}_{2}$ in rainwater was $25.20 \mu \mathrm{M}$ at $298 \mathrm{~K}$. The residual $\mathrm{H}_{2} \mathrm{O}_{2}$ in raindrops could enhance the level of liquid-phase $\mathrm{H}_{2} \mathrm{O}_{2}$ by up to $48.81 \mu \mathrm{M}$. The largest removal pathway of liquid-phase $\mathrm{H}_{2} \mathrm{O}_{2}$ was to oxidize dissolved $\mathrm{SO}_{2}$ into sulfate. Given that the major oxidants to sulfate formation were only $\mathrm{H}_{2} \mathrm{O}_{2}$ and $\mathrm{O}_{3}$ (Penkett et al., 1979; Chandler et al., 1988), the proportions of the $\mathrm{H}_{2} \mathrm{O}_{2}$ oxidation pathway to the overall, calculated by Eqs. (S12) and (S13) in the Supplement, were $92 \%$ at pH 5 and $11 \%$ at $\mathrm{pH} 6$, respectively. The average of sulfate concentration in rainwater was measured to be $31.95 \mu \mathrm{M}$, and the $\mathrm{H}_{2} \mathrm{O}_{2}$ oxidation pathway contributed to the sulfate with $29 \mu \mathrm{M}$ at $\mathrm{pH} 5$ and $4 \mu \mathrm{M}$ at $\mathrm{pH} 6$, which was the consumption molar concentration of $\mathrm{H}_{2} \mathrm{O}_{2}$. In addition, the decomposition of $\mathrm{H}_{2} \mathrm{O}_{2}$ during $6 \mathrm{~h}$ storage time before analysis was $6 \mu \mathrm{M}$ (Li et al., 2016). To summarize, the concentration of liquidphase $\mathrm{H}_{2} \mathrm{O}_{2}$ was supposed to have its maximum at $64.01 \mu \mathrm{M}$, a bit lower than the 90th percentile of the measured level $(67.85 \mu \mathrm{M})$. This could be considered to achieve the approximate balance between sources and sinks in the liquid-phase $\mathrm{H}_{2} \mathrm{O}_{2}$. Consequently, the residual $\mathrm{H}_{2} \mathrm{O}_{2}$ in raindrops could explain the difference between $H_{\mathrm{A}}^{\mathrm{m}}$ and $H_{\mathrm{A}}^{\mathrm{t}}$.

With respect to the sources and sinks for aerosol-phase $\mathrm{H}_{2} \mathrm{O}_{2}$, the main removal pathway was the consumption of $\mathrm{H}_{2} \mathrm{O}_{2}$ to sulfate formation, similar to the sink of $\mathrm{H}_{2} \mathrm{O}_{2}$ in the liquid phase. The average mass concentrations of $\mathrm{PM}_{2.5}$ and aerosol-phase $\mathrm{SO}_{4}^{2-}$ were 39.21 and $2.20 \mu \mathrm{g} \mathrm{m}^{-3}$, respectively. The mass concentration ratio of $\mathrm{SO}_{4}^{2-}$ to $\mathrm{PM}_{2.5}$ was $6 \%$ in this study, which was lower than previous studies (Ho et al., 2016; Shao et al., 2018). The discrepancy may be explained by the decreased ratio of $\mathrm{SO}_{4}^{2-}$ to $\mathrm{PM}_{2.5}$ due to $\mathrm{SO}_{2}$ emission control in recent years, as shown in the Supplement.

We estimated the contribution of different sources to the aerosol-phase $\mathrm{H}_{2} \mathrm{O}_{2}$ based on the formation and consumption rates. According to the previous estimation of the theoretical sulfate formation rate $\left(0.29 \mu \mathrm{g} \mathrm{m}^{-3} \mathrm{~h}^{-1}\right)$ and the average mass concentration of $\mathrm{PM}_{2.5}\left(106.19 \mu \mathrm{g} \mathrm{m}^{-3}\right)$ from 2 to 3 January 2019, the consumption rate of $\mathrm{H}_{2} \mathrm{O}_{2}$ should be $0.97 \mathrm{ng} \mathrm{\mu g}^{-1} \mathrm{~h}^{-1}$. With respect to the sources of the aerosolphase $\mathrm{H}_{2} \mathrm{O}_{2}$, the decomposition/hydrolysis of organic peroxides was firstly considered, with average rates of the rising stage for the first and second types (Fig. 6), 0.01 and $0.10 \mathrm{ng}_{\mu \mathrm{g}}^{-1} \mathrm{~h}^{-1}$, respectively. Because the extracted solution was stored under $255 \mathrm{~K}$, lower than the actual atmospheric temperature $(270 \mathrm{~K})$, the decomposition/hydrolysis rates of organic peroxides were underestimated and an adjusting factor should be multiplied. The factors for the three typical labile organic peroxides (HMHP, PFA, and PAA) were 13, 3, and 2, respectively, as shown in the Supplement. Assuming the factor was in the range of 2-13, the average decomposition/hydrolysis rate of organic peroxides for the first and second types $\left(0.055 \mathrm{ng} \mathrm{\mu g}^{-1} \mathrm{~h}^{-1}\right)$ was used to calculate the formation rate. The formation rate of the aerosol-phase $\mathrm{H}_{2} \mathrm{O}_{2}$ from the decomposition/hydrolysis of organic peroxides could account for $11 \%-74 \%$ of the consumption rate by sulfate formation. Moreover, the heterogeneous uptake of $\mathrm{HO}_{2}$ and $\mathrm{H}_{2} \mathrm{O}_{2}$ was also likely to improve the aerosol-phase $\mathrm{H}_{2} \mathrm{O}_{2}$ level at the rates of 0.22 and $0.02 \mathrm{ng} \mathrm{\mu g}^{-1} \mathrm{~h}^{-1}$, respectively, which can offset $22 \%$ and $2 \%$ of the consumption rate of $\mathrm{H}_{2} \mathrm{O}_{2}$, respectively. The source and sink rates of $\mathrm{H}_{2} \mathrm{O}_{2}$ did not seem to reach a balance. In our view, there were a few possible explanations for the difference. First, we estimated the contribution of the $\mathrm{H}_{2} \mathrm{O}_{2}$ oxidation pathway to sulfate formation during the entire measurement period based on the contribution of high-pollution days, which may overestimate the sink for the aerosol-phase $\mathrm{H}_{2} \mathrm{O}_{2}$. Second, the inverse dependence of the $\gamma$ value on the gas-phase $\mathrm{H}_{2} \mathrm{O}_{2}$ concentration was not considered, and the $\gamma$ value could be underestimated when the level of gas-phase $\mathrm{H}_{2} \mathrm{O}_{2}$ in winter was much lower (Romanias et al., 2012, 2013). Third, there may be missing sources in aerosol-phase $\mathrm{H}_{2} \mathrm{O}_{2}$ which are not completely understood.

Based on the above analysis, sources and sinks of $\mathrm{H}_{2} \mathrm{O}_{2}$ in the liquid phase could achieve a balance, while the formation of $\mathrm{H}_{2} \mathrm{O}_{2}$ from the decomposition/hydrolysis of aerosolphase organic peroxides and the heterogeneous uptake of $\mathrm{HO}_{2}$ and $\mathrm{H}_{2} \mathrm{O}_{2}$ could not offset the consumption of $\mathrm{H}_{2} \mathrm{O}_{2}$ in the aerosol phase. Field measurements and laboratory experiments are urgently needed to further study the possible reasons and search for missing sources of aerosol-phase $\mathrm{H}_{2} \mathrm{O}_{2}$. 


\section{Conclusions}

In this study, we simultaneously measured $\mathrm{H}_{2} \mathrm{O}_{2}$ concentrations in gas and rainwater in summer as well as in the gas and aerosol phases $\left(\mathrm{PM}_{2.5}\right)$ in winter over urban Beijing. For the seven investigated rain episodes, the average $H_{\mathrm{A}}^{\mathrm{m}}$ was $2.1 \times 10^{5} \mathrm{M} \mathrm{atm}^{-1}$, which was 2.5 times greater than $H_{\mathrm{A}}^{\mathrm{t}}$ at $298 \pm 2 \mathrm{~K}$. The liquid-phase concentration of $\mathrm{H}_{2} \mathrm{O}_{2}$ averaged $44.12 \pm 26.49 \mu \mathrm{M}$. In $69 \%$ of the rain samples, the liquidphase $\mathrm{H}_{2} \mathrm{O}_{2}$ level was much higher than the predicted value estimated for pure water using Henry's law. We found that $12 \%$ of measured $\mathrm{H}_{2} \mathrm{O}_{2}$ in all samples and $59 \%$ of measured $\mathrm{H}_{2} \mathrm{O}_{2}$ in those samples with high level of measured liquidphase $\mathrm{H}_{2} \mathrm{O}_{2}$ were from residual $\mathrm{H}_{2} \mathrm{O}_{2}$ in raindrops. With an increase in fall distance, the proportion of the additional source of liquid-phase $\mathrm{H}_{2} \mathrm{O}_{2}$ gradually increased. In addition, the sink of $\mathrm{H}_{2} \mathrm{O}_{2}$ due to droplet-to-gas transfer was reduced with an increase in raindrop diameter; thus, the liquid-phase $\mathrm{H}_{2} \mathrm{O}_{2}$ level also increased. Furthermore, the source and sink of $\mathrm{H}_{2} \mathrm{O}_{2}$ in rainwater could achieve a balance.

For the measured $\mathrm{PM}_{2.5}$ aerosol samples, a similar phenomenon was observed between the measured and predicted levels of $\mathrm{H}_{2} \mathrm{O}_{2}$ in the aerosol phase, but the difference was much higher than that in the liquid phase. $K_{\mathrm{P}}^{\mathrm{m}}$ averaged $3.8 \times 10^{-3} \mathrm{~m}^{3} \mu \mathrm{g}^{-1}$, which was 4 orders of magnitude higher than $K_{\mathrm{P}}^{\mathrm{t}}$ at $270 \pm 4 \mathrm{~K}$. The aerosol-phase concentration of $\mathrm{H}_{2} \mathrm{O}_{2}$ normalized to the aerosol mass averaged $0.093 \pm 0.085 \mathrm{ng} \mathrm{\mu g}^{-1}$. The decomposition/hydrolysis of organic peroxides produced the elevated aerosol-phase $\mathrm{H}_{2} \mathrm{O}_{2}$ at a maximum rate of $0.10 \mathrm{ng} \mathrm{\mu g}^{-1} \mathrm{~h}^{-1}$, responsible for $11 \%$ $74 \%$ of the consumption rate of aerosol-phase $\mathrm{H}_{2} \mathrm{O}_{2}$, and its value depended on the composition of organic peroxides in the aerosol particles. The heterogeneous uptake of $\mathrm{HO}_{2}$ and $\mathrm{H}_{2} \mathrm{O}_{2}$ played a minor role in increasing the $\mathrm{H}_{2} \mathrm{O}_{2}$ level in the aerosol phase, and the proportions based on the consumption rate of $\mathrm{H}_{2} \mathrm{O}_{2}$ were $22 \%$ and $2 \%$, respectively. There are many uncertainties in the decomposition/hydrolysis of organic peroxides in this study, and laboratory simulation studies are needed to quantify the roles of different organic peroxides in the decomposition process. Aerosol-phase $\mathrm{H}_{2} \mathrm{O}_{2}$ in this study cannot reach source and sink equilibrium, and there are missing sources of aerosol-phase $\mathrm{H}_{2} \mathrm{O}_{2}$. Due to a lack of substantial severe haze events with high RH in this study, the source and sink mentioned in the aerosol-phase $\mathrm{H}_{2} \mathrm{O}_{2}$ need to be further verified.

Our study has provided direct evidence to prove that the partitioning of $\mathrm{H}_{2} \mathrm{O}_{2}$ between the gas-liquid and gas-aerosol phases not only follows thermodynamic equilibrium but is also affected by certain physical and chemical reactions. The effective field-derived Henry's law constant and gasaerosol partitioning coefficient should be accepted to better predict the measured liquid- and aerosol-phase $\mathrm{H}_{2} \mathrm{O}_{2}$ concentrations, which would be beneficial to correctly calculating the contribution of $\mathrm{H}_{2} \mathrm{O}_{2}$ to the fast formation of $\mathrm{SO}_{4}^{2-}$ and $\mathrm{PM}_{2.5}$ during pollution episodes. More laboratory exper- iments and field measurements are urgently needed to improve our understanding of the partitioning of peroxides in different phases in the atmosphere.

Data availability. The data are accessible by contacting the corresponding author (zmchen@pku.edu.cn).

Supplement. The supplement related to this article is available online at: https://doi.org/10.5194/acp-20-5513-2020-supplement.

Author contributions. In the framework of BJ-2018Summer and BJ-2018Winter measurements, ZC and XX designed the study. XX carried out all peroxide measurements used in this study, analysed the data, and wrote the paper. ZC helped interpret the results, guided the writing, and modified the manuscript. YG contributed to the methods of analysing aerosol-phase hydrogen peroxide and total peroxides. HS helped interpret data and modified the manuscript. SC provided the data for the meteorological parameters, trace gases, and $\mathrm{PM}_{2.5}$ mass concentrations. All authors discussed the results and contributed to the final paper.

Competing interests. The authors declare that they have no conflict of interest.

Acknowledgements. We gratefully thank the editor and two anonymous reviewers for their constructive suggestions that helped us to improve the article.

Financial support. This research has been supported by the National Key Research and Development Program of China (grant no. 2016YFC0202704), the National Research Program for Key Issues in Air Pollution Control (grant no. DQGG0103), and the National Natural Science Foundation of China (grant no. 21477002).

Review statement. This paper was edited by Nga Lee Ng and reviewed by two anonymous referees.

\section{References}

Adamowicz, R. F.: A model for the reversible washout of sulfurdioxide, ammonia and carbon-dioxide from a polluted atmosphere and the production of sulfates in raindrops, Atmos. Environ., 13, 105-121, https://doi.org/10.1016/0004-6981(79)902506, 1979.

Arellanes, C., Paulson, S. E., Fine, P. M., and Sioutas, C.: Exceeding of Henry's law by hydrogen peroxide associated with urban aerosols, Environ. Sci. Technol., 40, 4859-4866, https://doi.org/10.1021/es0513786, 2006. 
Banerjee, D. K. and Budke, C. C.: Spectrophotometric determination of traces of peroxides in organic solvents, Anal. Chem., 36, 792-796, https://doi.org/10.1021/ac60210a027, 1964.

Baum, E. J.: Chemical property estimation: theory and application, CRC Press LLC, Florida, USA, 1998.

Campbell, S. J., Stevanovic, S., Miljevic, B., Bottle, S. E., Ristovski, Z., and Kalberer, M.: Quantification of particle-bound organic radicals in secondary organic aerosol, Environ. Sci. Technol., 53, 6729-6737, https://doi.org/10.1021/acs.est.9b00825, 2019.

Chandler, A. S., Choularton, T. W., Dollard, G. J., Eggleton, A. E. J., Gay, M. J., Hill, T. A., Jones, B. M. R., Tyler, B. J., Bandy, B. J., and Penkett, S. A.: Measurements of $\mathrm{H}_{2} \mathrm{O}_{2}$ and $\mathrm{SO}_{2}$ in clouds and estimates of their reaction rate, Nature, 336, 562-565, https://doi.org/10.1038/336562a0, 1988.

Charrier, J. G., McFall, A. S., Richards-Henderson, N. K., and Anastasio, C.: Hydrogen peroxide formation in a surrogate lung fluid by transition metals and quinones present in particulate matter, Environ. Sci. Technol., 48, 7010-7017, https://doi.org/10.1021/es501011w, 2014.

Chung, M. Y., Muthana, S., Paluyo, R. N., and Hasson, A. S.: Measurements of effective Henry's law constants for hydrogen peroxide in concentrated salt solutions, Atmos. Environ., 39, 29812989, https://doi.org/10.1016/j.atmosenv.2005.01.025, 2005.

Crowley, J. N., Pouvesle, N., Phillips, G. J., Axinte, R., Fischer, H., Petäjä, T., Nölscher, A., Williams, J., Hens, K., Harder, H., Martinez-Harder, M., Novelli, A., Kubistin, D., Bohn, B., and Lelieveld, J.: Insights into $\mathrm{HO}_{x}$ and $\mathrm{RO}_{x}$ chemistry in the boreal forest via measurement of peroxyacetic acid, peroxyacetic nitric anhydride (PAN) and hydrogen peroxide, Atmos. Chem. Phys., 18, 13457-13479, https://doi.org/10.5194/acp-18-134572018, 2018.

Docherty, K. S., Wu, W., Lim, Y. B., and Ziemann, P. J.: Contributions of organic peroxides to secondary aerosol formed from reactions of monoterpenes with $\mathrm{O}_{3}$, Environ. Sci. Technol., 39, 4049-4059, https://doi.org/10.1021/es050228s, 2005.

Elperin, T. and Fominykh, A.: Conjugate mass transfer during gas absorption by falling liquid droplet with internal circulation, Atmos. Environ., 39, 4575-4582, https://doi.org/10.1016/j.atmosenv.2005.04.005, 2005.

Epstein, S. A., Blair, S. L., and Nizkorodov, S. A.: Direct photolysis of $\alpha$-pinene ozonolysis secondary organic aerosol: effect on particle mass and peroxide content, Environ. Sci. Technol., 48, 11251-11258, https://doi.org/10.1021/es502350u, 2014.

Gong, Y., Chen, Z., and Li, H.: The oxidation regime and SOA composition in limonene ozonolysis: roles of different double bonds, radicals, and water, Atmos. Chem. Phys., 18, 1510515123, https://doi.org/10.5194/acp-18-15105-2018, 2018.

Gunn, R. and Kinzer, G. D.: The terminal velocity of fall for water droplets in stagnant air, J. Meteorol., 6, 243-248, https://doi.org/10.1175/15200469(1949)006<0243:TTVOFF>2.0.CO;2, 1949.

Gurgueira, S. A., Lawrence, J., Coull, B., Murthy, G. G. K., and González-Flecha, B.: Rapid increases in the steady-state concentration of reactive oxygen species in the lungs and heart after particulate air pollution inhalation, Environ. Health Perspect., 110, 749-755, https://doi.org/10.1289/ehp.02110749, 2002.

Hasson, A. S. and Paulson, S. E.: An investigation of the relationship between gas-phase and aerosol-borne hy- droperoxides in urban air, J. Aerosol Sci., 34, 459-468, https://doi.org/10.1016/S0021-8502(03)00002-8, 2003.

He, S. Z., Chen, Z. M., Zhang, X., Zhao, Y., Huang, D. M., Zhao, J. N., Zhu, T., Hu, M., and Zeng, L. M.: Measurement of atmospheric hydrogen peroxide and organic peroxides in Beijing before and during the 2008 Olympic Games: chemical and physical factors influencing their concentrations, J. Geophys. Res., 115, D17307, https://doi.org/10.1029/2009JD013544, 2010.

Ho, K. F., Ho, S. S. H., Huang, R. J., Chuang, H. C., Cao, J. J., Han, Y. M., Lui, K. H., Ning, Z., Chuang, K. J., Cheng, T. J., Lee, S. C., Hu, D., Wang, B., and Zhang, R. J.: Chemical composition and bioreactivity of $\mathrm{PM}_{2.5}$ during 2013 haze events in China, Atmos. Environ., 126, 162-170, https://doi.org/10.1016/j.atmosenv.2015.11.055, 2016.

Hua, W., Chen, Z. M., Jie, C. Y., Kondo, Y., Hofzumahaus, A., Takegawa, N., Chang, C. C., Lu, K. D., Miyazaki, Y., Kita, K., Wang, H. L., Zhang, Y. H., and Hu, M.: Atmospheric hydrogen peroxide and organic hydroperoxides during PRIDE-PRD'06, China: their concentration, formation mechanism and contribution to secondary aerosols, Atmos. Chem. Phys., 8, 6755-6773, https://doi.org/10.5194/acp-8-6755-2008, 2008.

Huang, D. M. and Chen, Z. M.: Reinvestigation of the Henry's law constant for hydrogen peroxide with temperature and acidity variation, J. Environ. Sci., 22, 570-574, https://doi.org/10.1016/S1001-0742(09)60147-9, 2010.

Huang, L. B., Zhao, Y., Li, H., and Chen, Z. M.: Kinetics of heterogeneous reaction of sulfur dioxide on authentic mineral dust: effects of relative humidity and hydrogen peroxide, Environ. Sci. Technol., 49, 10797-10805, https://doi.org/10.1021/acs.est.5b03930, 2015.

Kirkby, J., Duplissy, J., Sengupta, K., Frege, C., Gordon, H., Williamson, C., Heinritzi, M., Simon, M., Yan, C., Almeida, J., Tröstl, J., Nieminen, T., Ortega, I. K., Wagner, R., Adamov, A., Amorim, A., Bernhammer, A. K., Bianchi, F., Breitenlechner, M., Brilke, S., Chen, X. M., Craven, J., Dias, A., Ehrhart, S., Flagan, R. C., Franchin, A., Fuchs, C., Guida, R., Hakala, J., Hoyle, C. R., Jokinen, T., Junninen, H., Kangasluoma, J., Kim, J., Krapf, M., Kürten, A., Laaksonen, A., Lehtipalo, K., Makhmutov, V., Mathot, S., Molteni, U., Onnela, A., Peräkylä, O., Piel, F., Petäjä, T., Praplan, A. P., Pringle, K., Rap, A., Richards, N. A. D., Riipinen, I., Rissanen, M. P., Rondo, L., Sarnela, N., Schobesberger, S., Scott, C. E., Seinfeld, J. H., Sipilä, M., Steiner, G., Stozhkov, Y., Stratmann, F., Tomé, A., Virtanen, A., Vogel, A. L., Wagner, A. C., Wagner, P. E., Weingartner, E., Wimmer, D., Winkler, P. M., Ye, P. L., Zhang, X., Hansel, A., Dommen, J., Donahue, N. M., Worsnop, D. R., Baltensperger, U., Kulmala, M., Carslaw, K. S., and Curtius, J.: Ion-induced nucleation of pure biogenic particles, Nature, 533, 521-526, https://doi.org/10.1038/nature17953, 2016.

Krapf, M., EI Haddad, I., Bruns, E. A., Molteni, U., Daellenbach, K. R., Prévôt, A. S. H., Baltensperger, U., and Dommen, J.: Labile peroxides in secondary organic aerosol, Chem, 1, 603-616, https://doi.org/10.1016/j.chempr.2016.09.007, 2016.

Kuang, Y., Tao, J. C., Xu, W. Y., Yu, Y. L., Zhao, G., Shen, C. Y., Bian, Y. X., and Zhao, C. S.: Calculating ambient aerosol surface area concentrations using aerosol light scattering enhancement measurements, Atmos. Environ., 216, 116919, https://doi.org/10.1016/j.atmosenv.2019.116919, 2019. 
Kumar, S.: An Eulerian model for scavenging of pollutants by raindrops, Atmos. Environ., 19, 769-778, https://doi.org/10.1016/0004-6981(85)90065-4, 1985.

Lee, M. H., Heikes, B. G., and O'Sullivan, D. W.: Hydrogen peroxide and organic hydroperoxide in the troposphere: a review, Atmos. Environ., 34, 3475-3494, https://doi.org/10.1016/S13522310(99)00432-X, 2000.

Levine, S. Z. and Schwartz, S. E.: In-cloud and below-cloud scavenging of nitric acid vapor, Atmos. Environ., 16, 1725-1734, https://doi.org/10.1016/0004-6981(82)90266-9, 1982.

Li, H., Chen, Z., Huang, L., and Huang, D.: Organic peroxides' gasparticle partitioning and rapid heterogeneous decomposition on secondary organic aerosol, Atmos. Chem. Phys., 16, 1837-1848, https://doi.org/10.5194/acp-16-1837-2016, 2016.

Li, K., Jacob, D. J., Liao, H., Zhu, J., Shah, V., Shen, L., Bates, K. H., Zhang, Q., and Zhai, S. X.: A two-pollutant strategy for improving ozone and particulate air quality in China, Nat. Geosci., 12, 906-910, https://doi.org/10.1038/s41561-019-0464-x, 2019.

Li, T., Wang, Z., Wang, Y., Wu, C., Liang, Y., Xia, M., Yu, C., Yun, H., Wang, W., Wang, Y., Guo, J., Herrmann, H., and Wang, T.: Chemical characteristics of cloud water and the impacts on aerosol properties at a subtropical mountain site in Hong Kong SAR, Atmos. Chem. Phys., 20, 391-407, https://doi.org/10.5194/acp-20-391-2020, 2020.

Liang, H., Chen, Z. M., Huang, D., Zhao, Y., and Li, Z. Y.: Impacts of aerosols on the chemistry of atmospheric trace gases: a case study of peroxides and $\mathrm{HO}_{2}$ radicals, Atmos. Chem. Phys., 13, 11259-11276, https://doi.org/10.5194/acp-13-112592013, 2013.

Lind, J. A. and Kok, G. L.: Henry's law determinations for aqueous solutions of hydrogen peroxide, methylhydroperoxide, and peroxyacetic acid, J. Geophys. Res., 91, 7889-7895, https://doi.org/10.1029/JD091iD07p07889, 1986.

Liu, T. Y., Clegg, S. L., and Abbatt, J. P. D.: Fast oxidation of sulfur dioxide by hydrogen peroxide in deliquesced aerosol particles, P. Natl. Acad. Sci. USA, 117, 1354-1359, https://doi.org/10.1073/pnas.1916401117, 2020.

Liu, Y. C., Wu, Z. J., Wang, Y., Xiao, Y., Gu, F. T., Zheng, J., Tan, T. Y., Shang, D. J., Wu, Y. S., Zeng, L. M., Hu, M., Bateman, A. P., and Martin, S. T.: Submicrometer particles are in the liquid state during heavy haze episodes in the urban atmosphere of Beijing, China, Environ. Sci. Technol. Lett., 4, 427432, https://doi.org/10.1021/acs.estlett.7b00352, 2017.

Ma, X. F., Tan, Z. F., Lu, K. D., Yang, X. P., Liu, Y. H., Li, S. L., Li, X., Chen, S. Y., Novelli, A., Cho, C. M., Zeng, L. M., Wahner, A., and Zhang, Y. H.: Winter photochemistry in Beijing: observation and model simulation of $\mathrm{OH}$ and $\mathrm{HO}_{2}$ radicals at an urban site, Sci. Total Environ., 685, 85-95, https://doi.org/10.1016/j.scitotenv.2019.05.329, 2019.

Maass, O. and Hiebert, P. G.: The properties of pure hydrogen peroxide. v. vapor pressure, J. Am. Chem. Soc., 46, 2693-2700, https://doi.org/10.1021/ja01677a012, 1924.

Nozaki, K.: Iodometric method of analysis for organic peroxides, Ind. Eng. Chem., 18, 583-583, https://doi.org/10.1021/i560157a020, 1946.

O'Sullivan, D. W., Lee, M., Noone, B. C., and Heikes, B. G.: Henry's law constant determinations for hydrogen peroxide, methyl hydroperoxide, hydroxymethyl hydroperoxide, ethyl hy- droperoxide, and peroxyacetic acid, J. Phys. Chem., 100, 32413247, https://doi.org/10.1021/jp951168n, 1996.

Pankow, J. F.: An absorption model of gas-particle partitioning of organic compounds in the atmosphere, Atmos. Environ., 28, 185-188, https://doi.org/10.1016/1352-2310(94)90093-0, 1994.

Penkett, S. A., Jones, B. M. R., Brich, K. A., and Eggleton, A. E. J.: The importance of atmospheric ozone and hydrogen peroxide in oxidising sulphur dioxide in cloud and rainwater, Atmos. Environ., 13, 123-137, https://doi.org/10.1016/j.atmosenv.2007.10.065, 1979.

Pradhan, M., Kyriakou, G., Archibald, A. T., Papageorgiou, A. C., Kalberer, M., and Lambert, R. M.: Heterogeneous uptake of gaseous hydrogen peroxide by Gobi and Saharan dust aerosols: a potential missing sink for $\mathrm{H}_{2} \mathrm{O}_{2}$ in the troposphere, Atmos. Chem. Phys., 10, 7127-7136, https://doi.org/10.5194/acp-107127-2010, 2010.

Pruppacher, H. R. and Klett, J. D.: Microphysics of clouds and precipitation, Kluwer Academic Publishers, Dordrecht, the Netherlands, 1997.

Qin, M. R., Chen, Z. M., Shen, H. Q., Li, H., Wu, H. H., and Wang, Y.: Impacts of heterogeneous reactions to atmospheric peroxides: observations and budget analysis study, Atmos. Environ., 183, 144-153, https://doi.org/10.1016/j.atmosenv.2018.04.005, 2018.

Qiu, J., Ishizuka, S., Tonokura, K., Colussi, A. J., and Enami, S.: Water dramatically accelerates the decomposition of $\alpha$-hydroxyalkyl-hydroperoxides in aerosol particles, J. Phys. Chem. Lett., 10, 5748-5755, https://doi.org/10.1021/acs.jpclett.9b01953, 2019.

Reeves, C. E. and Penkett, S. A.: Measurements of peroxides and what they tell us, Chem. Rev., 103, 5199-5218, https://doi.org/10.1021/cr0205053, 2003.

Riva, M., Budisulistiorini, S. H., Zhang, Z. F., Gold, A., Thornton, J. A., Turpin, B. J., and Surratt, J. D.: Multiphase reactivity of gaseous hydroperoxide oligomers produced from isoprene ozonolysis in the presence of acidified aerosols, Atmos. Environ., 152, 314-322, https://doi.org/10.1016/j.atmosenv.2016.12.040, 2017.

Romanias, M. N., El Zein, A., and Bedjanian, Y.: Heterogeneous interaction of $\mathrm{H}_{2} \mathrm{O}_{2}$ with $\mathrm{TiO}_{2}$ surface under dark and UV light irradiation conditions, J. Phys. Chem. A, 116, 8191-8200, https://doi.org/10.1021/jp305366v, 2012.

Romanias, M. N., El Zein, A., and Bedjanian, Y.: Uptake of hydrogen peroxide on the surface of $\mathrm{Al}_{2} \mathrm{O}_{3}$ and $\mathrm{Fe}_{2} \mathrm{O}_{3}$, Atmos. Environ., 77, 1-8, https://doi.org/10.1016/j.atmosenv.2013.04.065, 2013.

Sander, S. P., Abbatt, J., Barker, J. R., Burkholder, J. B., Friedl, R. R., Golden, D. M., Huie, R. E., Kolb, C. E., Kurylo, M. J., Moortgat, G. K., Orkin, V. L., and Wine, P. H.: Chemical kinetics and photochemical data for use in atmospheric studies, Evaluation No. 17, JPL Publication 10-6, Jet Propulsion Laboratory, Pasadena, USA, available at: http://jpldataeval.jpl.nasa.gov (last access: 19 March 2020), 2011.

Seinfeld, J. H. and Pandis S. N.: Atmospheric chemistry and physics: from air pollution to climate change, 2nd Edition, John Wiley and Sons, New Jersey, USA, 2006.

Shang, B., Zhou, Y. Q., Liu, J. C., and Huang, Y. M.: Comparing vertical structure of precipitation cloud and nonprecipitation cloud using Cloudsat, J. Appl. Meteor. Sci., 23, 1-9, https://doi.org/10.3969/j.issn.1001-7313.2012.01.001, 2012. 
Shao, P. Y., Tian, H. Z., Sun, Y. J., Liu, H. J., Wu, B. B., Liu, S. H., Liu, X. Y., Wu, Y. M., Liang, W. Z., Wang, Y., Gao, J. J., Xue, Y. F., Bai, X. X., Liu, W., Lin, S. M., and $\mathrm{Hu}$, G. Z.: Characterizing remarkable changes of severe haze events and chemical compositions in multi-size airborne particles $\left(\mathrm{PM}_{1}, \mathrm{PM}_{2.5}\right.$ and $\left.\mathrm{PM}_{10}\right)$ from January 2013 to 20162017 winter in Beijing, China, Atmos. Environ., 189, 133-144, https://doi.org/10.1016/j.atmosenv.2018.06.038, 2018.

Shen, H., Barakat, A. I., and Anastasio, C.: Generation of hydrogen peroxide from San Joaquin Valley particles in a cell-free solution, Atmos. Chem. Phys., 11, 753-765, https://doi.org/10.5194/acp11-753-2011, 2011.

Shen, H. Q., Chen, Z. M., Li, H., Qian, X., Qin, X., and Shi, W. X.: Gas-particle partitioning of carbonyl compounds in the ambient atmosphere, Environ. Sci. Technol., 52, 10997-11006, https://doi.org/10.1021/acs.est.8b01882, 2018.

Shiraiwa, M., Ammann, M., Koop, T., and Pöschl, U.: Gas uptake and chemical aging of semisolid organic aerosol particles, P. Natl. Acad. Sci. USA, 108, 11003-11008, https://doi.org/10.1073/pnas.1103045108, 2011.

Slade, J. H. and Knopf, D. A.: Multiphase $\mathrm{OH}$ oxidation kinetics of organic aerosol: the role of particle phase state and relative humidity, Geophys. Res. Lett., 41, 5297-5306, https://doi.org/10.1002/2014GL060582, 2015.

Stein, A. F. and Saylor, R. D.: Sensitivities of sulfate aerosol formation and oxidation pathways on the chemical mechanism employed in simulations, Atmos. Chem. Phys., 12, 8567-8574, https://doi.org/10.5194/acp-12-8567-2012, 2012.

Tong, H., Arangio, A. M., Lakey, P. S. J., Berkemeier, T., Liu, F., Kampf, C. J., Brune, W. H., Pöschl, U., and Shiraiwa, M.: Hydroxyl radicals from secondary organic aerosol decomposition in water, Atmos. Chem. Phys., 16, 1761-1771, https://doi.org/10.5194/acp-16-1761-2016, 2016.

Wang, Y., Kim, H., and Paulson, S. E.: Hydrogen peroxide generation from $\alpha$ - and $\beta$-pinene and toluene secondary organic aerosols, Atmos. Environ., 45, 3149-3156, https://doi.org/10.1016/j.atmosenv.2011.02.060, 2011.

Wang, Y., Chen, Z., Wu, Q., Liang, H., Huang, L., Li, H., Lu, K., Wu, Y., Dong, H., Zeng, L., and Zhang, Y.: Observation of atmospheric peroxides during Wangdu Campaign 2014 at a rural site in the North China Plain, Atmos. Chem. Phys., 16, 10985-11000, https://doi.org/10.5194/acp-16-10985-2016, 2016.

Williams, B. J., Goldstein, A. H., Kreisberg, N. M., and Hering, S. V.: In situ measurements of gas/particlephase transitions for atmospheric semivolatile organic compounds, P. Natl. Acad. Sci. USA, 107, 6676-6681, https://doi.org/10.1073/pnas.0911858107, 2010.
Wu, Q. Q., Huang, L. B., Liang, H., Zhao, Y., Huang, D., and Chen, Z. M.: Heterogeneous reaction of peroxyacetic acid and hydrogen peroxide on ambient aerosol particles under dry and humid conditions: kinetics, mechanism and implications, Atmos. Chem. Phys., 15, 6851-6866, https://doi.org/10.5194/acp15-6851-2015, 2015.

Xie, M. J., Hannigan, M. P., and Barsanti, K. C.: Gas/particle partitioning of n-alkanes, PAHs and oxygenated PAHs in urban Denver, Atmos. Environ., 95, 355-362, https://doi.org/10.1016/j.atmosenv.2014.06.056, 2014.

$\mathrm{Xu}$, Z. F., Tang, Y., and Ji, J. P.: Chemical and strontium isotope characterization of rainwater in Beijing during the 2008 Olympic year, Atmos. Res., 107, 115-125, https://doi.org/10.1016/j.atmosres.2012.01.002, 2012.

Ye, C., Liu, P. F., Ma, Z. B., Xue, C. Y., Zhang, C. L., Zhang, Y. Y., Liu, J. F., Liu, C. T., Sun, X., and Mu, Y. J.: High $\mathrm{H}_{2} \mathrm{O}_{2}$ concentrations observed during haze periods during the winter in Beijing: importance of $\mathrm{H}_{2} \mathrm{O}_{2}$ oxidation in sulfate formation, Environ. Sci. Technol. Lett., 5, 757-763, https://doi.org/10.1021/acs.estlett.8b00579, 2018.

Zhao, R., Kenseth, C. M., Huang, Y., Dalleska, N. F., and Seinfeld, J. H.: Iodometry-assisted liquid chromatography electrospray ionization mass spectrometry for analysis of organic peroxides: an application to atmospheric secondary organic aerosol, Environ. Sci. Technol., 52, 2108-2117, https://doi.org/10.1021/acs.est.7b04863, 2018.

Zhao, Y., Chen, Z. M., Shen, X. L., and Zhang, X.: Kinetics and mechanisms of heterogeneous reaction of gaseous hydrogen peroxide on mineral oxide particles, Environ. Sci. Technol., 45, 3317-3324, https://doi.org/10.1021/es104107c, 2011.

Zhao, Y., Chen, Z. M., Shen, X. L., and Huang, D.: Heterogeneous reactions of gaseous hydrogen peroxide on pristine and acidic gas-processed calcium carbonate particles: effects of relative humidity and surface coverage of coating, Atmos. Environ., 67, 6372, https://doi.org/10.1016/j.atmosenv.2012.10.055, 2013.

Zhou, X. L., Davis, A. J., Kieber, D. J., Keene, W. C., Maben, J. R., Maring, H., Dahl, E. E., Izaguirre, M. A., Sander, R., and Smoydzyn, L.: Photochemical production of hydroxyl radical and hydroperoxides in water extracts of nascent marine aerosols produced by bursting bubbles from Sargasso seawater, Geophys. Res. Lett., 35, L20803, https://doi.org/10.1029/2008GL035418, 2008. 